\title{
Factors controlling sedimentation in the Torun-Eberswalde ice-marginal valley during the Pomeranian phase of the Weichselian glaciation: an overview
}

\author{
Małgorzata Pisarska-Jamroży \\ Institute of Geology, Adam Mickiewicz University, Maków Polnych 16, 61-606 Poznań, Poland; \\ e-mail: pisanka@amu.edu.pl
}

\begin{abstract}
During the Pleistocene the Scandinavian ice sheet drained huge quantities of sediment-laden meltwaters. These meltwaters supplied ice-marginal valleys that formed parallel to the front of the ice sheet. Not without significance was the supply of ice-marginal valleys from extraglacial rivers in the south. Moreover, periglacial conditions during and after sedimentation in ice-marginal valleys, the morphology of valley bedrocks, and erosion of older sediments played important roles in the depositional scenarios, and in the mineralogical composition of the sediments. The mechanisms that controlled the supply and deposition in ice-marginal valleys were analysed on the basis of a Pleistocene ice-marginal valley that was supplied by northern and southern source areas in the immediate vicinity. Investigations were conducted in one of the largest ice-marginal valleys of the Polish-German lowlands, i.e., the Torun-Eberswalde ice-marginal valley, in sandurs (Drawa and Gwda) supplied sediments and waters from the north into this valley, and on extraglacial river terraces (pre-Noteć and pre-Warta rivers), formed simultaneously with the sandurs and ice-marginal valley (Pomeranian phase of Weichselian glaciation) supplied sediments and waters from the south into this valley. A much debated question is how similar, or different, depositional processes and sediments were that contributed to the formation of the Torun-Eberswalde ice-marginal valley, and whether or not it is possible to differentiate mostly rapidly aggraded sandur sediments from ice-marginal valley sediments. Another question addresses the contribution of extraglacial feeding of the Torun-Eberswalde ice-marginal valley. These matters were addressed by a wide range of analyses: sediment texture and structure, architectural elements of sediments, frequency of sedimentary successions, heavy-mineral analysis (both transparent and opaque heavy minerals), analysis of rounding and frosting of quartz grains, and palaeohydrological calculations. Additionally, a statistical analysis was used. The specific depositional conditions of distribution of sediments in ice-marginal valley allow to distinguish new environment of ice-marginal valley braided river. The spectrum of depositional conditions in the Torun-Eberswalde ice-marginal valley and their specific palaeohydraulic parameters allow to distinguish three coexisting zones in the ice-marginal valley braided-river system: (1) deep gravel-bed braided channel zone with extensive scours, (2) deep sand-bed braided channel zone with transverse bars, and (3) marginal sand-bed and gravel-bed braided channel zone with diamicton and breccia deposition, which were characterised in detail. Some of the results have been published previously, which is why they are discussed in the present paper within the context of new data.
\end{abstract}

Keywords: sedimentology, depositional mechanisms, palaeohydraulics, heavy minerals, sandur, Pleistocene, Poland 


\section{Introduction}

The term ice-marginal valleys (abbreviated to IMVs, also referred to as pradolinas, Urstromtäler, spillways, ice-marginal streamways, meltwater valleys, vallées marginales proglaciaires) generally was used for broad valleys (up to $25 \mathrm{~km}$ ) that formed parallel to the ice front margin of Pleistocene ice sheets, and collected conjoined waters from proglacial meltwater channels and extraglacial rivers which drained the ice-free areas (Woldstedt, 1950; Galon, 1961; Kozarski, 1962; Niewiarowski, 1969; Wiśniewski, 1971, 1990, 1992; Jaroszewski et al., 1985; Mizerski \& Sylwestrzak, 2002; Goudie, 2004; Migon, 2006; Marks, 2012). In Europe IMVs occur across the North European Plain from Russia to the North Sea. The term IMVs is also used in North America (Goudie, 2004; Kehew et al., 2009) and in New Zealand (Soons, 1964), but in these countries the meaning is slightly different - in New Zealand IMVs are described as valleys that roughly parallel the ice edge, utilising pre-existing ice-free valleys, while North American IMVs usually are referred to as spillways and are connected with megafloods (Kehew et al., 2009). The term proglacial spillway, connected with megafloods, is employed in Latvia (Zelčs \& Markots, 2004; Zelčs et al., 2011) as well. Only two terms, 'pradolina' and 'Urstromtal' clearly define the marginal currents that were parallel to the front of an ice sheet. Important for the occurrence of IMVs in Europe is the fact that, in general, they all lie on south to north sloping land, which had an influence on the flow direction. During the Pleistocene, the ice sheet blocked the northerly outflow of rivers to the present-day Baltic Sea Basin, so rivers from the south generally flowed westwards parallel to the line that indicates the extent of the ice sheet. The meltwaters flowed southwards over the sandurs (=outwash, outwash plain), as based on sandur slope, and then joined extraglacial rivers - westwards in IMV. Rivers such as the Rhine and Meuse in the Netherlands, the Weser, Ems and Elbe in Germany, and the Odra and Wisła (Vistula) in Poland were successively redirected during Pleistocene glaciations to a westward course, and then northwards (Galon, 1968; Toucanne et al., 2009a, b, 2010). However, in English literature often both terms (Polish 'pradolina'; German 'Urstromtal') are rejected by reviewers (e.g., in Pisarska-Jamroży \& Zieliński, 2011; Pisarska-Jamroży, 2013).

The definition of IMVs from the beginning of this section has a common denominator - geomorphological meaning, while 'IMV environment' represents a wide spectrum of specific depositional processes and sediments. Only a few IMV descriptions include processes; for instance, the thermoerosion process as an important factor of IMV development was described by Jahn (1975), Lindner (1992), Pisarska-Jamroży \& Zieliński (2011) and Weckwerth \& Pisarska-Jamroży (in press). In addition, only in some descriptions of IMVs is the origin of terrace formation and of some parts of IMV described (Galon, 1961; Kozarski, 1962; Brodzikowski \& Van Loon, 1991; Kondracki, 2000; Börner, 2007; Weckwerth, 2013).

The main Pleistocene IMVs of the Polish-German lowlands (Fig. 1A) are the Wrocław-Magdeburg-Bremen, the Głogów-Baruth-Hamburg, the Vilnius-Warsaw-Poznań-Berlin and the Toruń-Eberswalde (Noteć-Warta). They all were formed during successive cold stages, from the Saalian (130-200 kyr BP) to the Pomeranian phase of the Weichselian (16-17 kyr BP; Marks, 2012). The glaciation-related Torun-Eberswalde IMV (Fig. 1A) studied here drained the water from proglacial streams of Pomeranian sandurs (=sandurs developed during the Pomeranian phase) and extraglacial areas (e.g. through pre-Warta and pre-Noteć rivers) during the maximum extent of the Pomeranian phase (16-17 kyr BP; Marks, 2012) and Angermünde-Chojna subphase of the Pomeranian phase

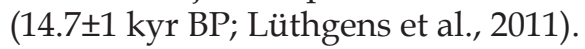

The Torun-Eberswalde IMV has raised many controversies over its origin and development. The origin and function of this IMV has been studied from the start of the twentieth century (Maas, 1904; Ost, 1932, 1935; Woldstedt, 1935; Louis, 1936; Galon, 1961; Liedtke, 1961; Kozarski, 1965, 1966 and others), and although the relationships between the sandurs and the IMV have been discussed previously (see, among others, Galon, 1961; Kozarski, 1965; Wiśniewski, 1971), no details are available to date on the sources of sediments deposited in the Torun-Eberswalde IMV. Sandur rivers mainly supplied the Torun-Eberswalde IMV in the form of ablation floods. Ablation floods are common hydrological features of sandurs (Boothroyd \& Ashley, 1975; Church \& Gilbert, 1975; Maizels, 1993; Krüger, 1997; Warburton, 1999), as well as rare megafloods (Paterson, 1994; Bjørnsson, 1998; Russell \& Marren, 1999; Marren et al., 2002; Snorrason et al., 2002; Van Loon, 2009). The commonly accepted view is that extraglacial rivers coming from the south were an important sediment source in the Torun-Eberswalde IMV (see Galon, 1968; Wiśniewski, 1990, 1992). Although it cannot be proved, this extraglacial source has been taken for granted ever since.

The river in the Torun-Eberswalde IMV was characterised by numerous channels of a periglacial braided fluvial system, which is indicated by 

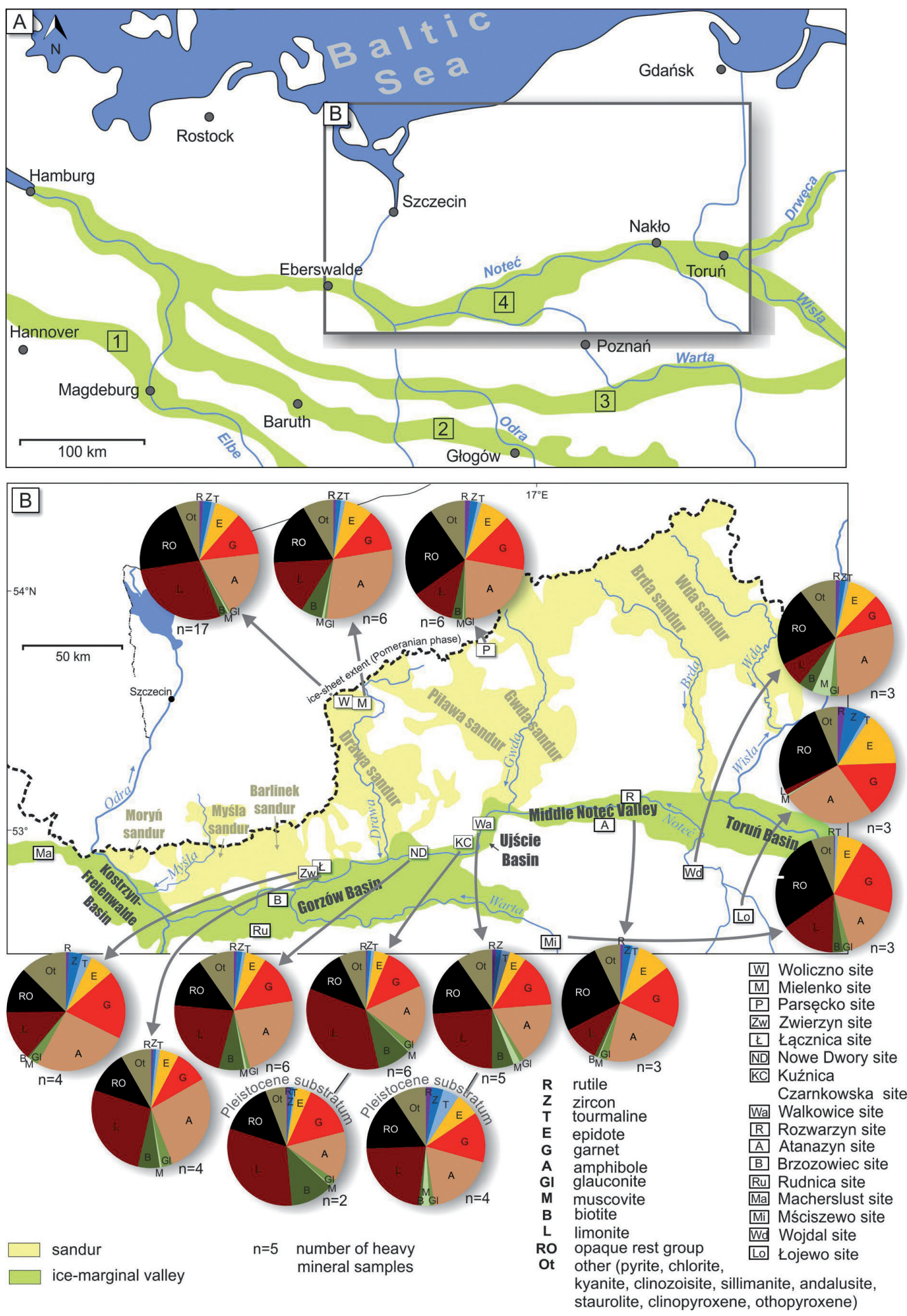

Fig. 1. Location of the study area in the Polish-German Lowland.

A - Positions of the ice-marginal valleys in the Polish-German Lowland (1 - Wrocław-Magdeburg-Bremen ice-marginal valley, 2 - Głogów-Baruth-Hamburg ice-marginal valley, 3 - Vilnius-Warsaw-Poznań-Berlin ice-marginal valley, 4 - Torun-Eberswalde ice-marginal valley); B - Location of study sites in the Pomeranian sandurs, the Torun-Eberswalde ice-marginal valley and from pre-Noteć River and pre-Warta River with heavy-mineral spectra (Pisarska-Jamroży et al., in press a, supplemented). 
the large width of the valley in comparison to its depth (1,000:3), and by slightly curved valley banks (Kozarski, 1965). The main phase of fluvioperiglacial sedimentation in the Torun-Eberswalde IMV was dated as 16-17 kyr (Weckwerth, 2013). The periglacial climate favoured extensive lateral thermoerosion of the channel banks (consisting of till plain and glaciofluvial sediments of older sandurs) and debris flows derived from till plain. Both these processes supplied large amounts of sediment into the river channels and caused the marginal channels of the river to braid. All these processes also explain why the calculated palaeohydraulic parameters of the studied part of the Torun-Eberswalde IMV (from the Noteć Middle Valley to the Gorzów Basin) are clearly different from the Pleistocene rivers of the European Plain. Up to now, calculations were made for the Torun Basin, i.e., the eastern part of the Torun-Eberswalde IMV (Weckwerth, 2013), and for the Warsaw-Poznań-Berlin IMV which predates the Torun-Eberswalde IMV (Antczak, 1985, 1986).

The aims of the present study are (1) to identify the main sediment sources in the part of IMV studied; (2) to establish the contribution of extraglacial rivers in sediment supply of IMV; (3) to further our understanding of the relationship between the depositional environment of sandur and IMV and to show differences between braided fluvial systems on sandur and in IMV; (4) to summarise the role of periglacial conditions in controlling fluvial transport and deposition in the braided river system of IMV; (5) to calculate the main palaeohydrological parameters of the IMV river; (6) to characterise specific zones of the braided river system in IMV; and (7) to explain the significance of sediments derived from hyperconcentrated flow for depositional conditions in IMV.

\section{Geological and geomorphological setting}

The maximum extent of the Late Pleistocene Weichselian ice-sheet (Leszno-Brandenburg phase) was reached 19-24 kyr BP (Marks, 2012). A second ice re-advance took place 19-20 kyr BP (Poznań-Frankfurt phase), and a third around 16-17 kyr BP (Pomeranian phase). During the Pomeranian phase three subphases can be recognised: maximum, Angermünde-Chojna (Kozarski, 1965), and according to Karczewski (1968), Mielęcin subphase. The sandurs Drawa, Gwda, Brda and Wda (Fig. 1B) were formed during the Pomeranian phase. The sandurs studied, i.e., Drawa and Gwda, are examples of large ones (80 and $110 \mathrm{~km}$ long, respectively), which directly supplied the studied part of IMV. The Torun-Eberswalde IMV, comprising the Torun Basin, Middle Noteć Valley (=Noteć Valley), the Ujście Basin, the Gorzów Basin, the Kostrzyn-Freienwalde Basin and the Eberswalde Valley, is one of the largest ( $>500 \mathrm{~km}$ long, $2-20 \mathrm{~km}$ wide) IMVs of the European Plain (Fig. 1A); it is incised into a till plain of the Brandenburg-Leszno phase and sandurs. The study area $-300 \mathrm{~km}$ long - the middle and western parts of the Torun-Eberswalde IMV (Fig. 1B) starts from Rozwarzyn (69-70 $m$ a.s.l.) in the east and ends in Macherslust near Eberswalde ( $36 \mathrm{~m}$ a.s.l.) in the west. In this area ten sites were investigated sedimentologically and tested for heavy mineral composition: Rozwarzyn, Atanazyn, Walkowice, Kuźnica Czarnkowska, Nowe Dwory, Łącznica, Zwierzyn, Brzozowiec, Rudnica and Macherslust (Fig. 1B).

In the part of the Torun-Eberswalde IMV studied here, three terraces lying above floodplain (I) have been distinguished: lower IMV terrace (II) and upper IMV terrace (III) and, in some reaches, also an uppermost (IV) (Kozarski, 1962). Nine of ten sites studied (i.e., all except the Macherslust site) are located on the third terrace (Kozarski, 1986; Pisarska-Jamroży \& Zieliński, 2011; Weckwerth \& Pisarska-Jamroży, in press). Core deposits of the third terrace consist of till and/or glaciofluvial deposits with an erosional top, overlain by a gravelly pavement which is succeeded by several metres of fluvial sands on the surface of which occur shallow lakes. Stankowski (1963a, b) described in many places an aeolian relief of this terrace. The third terrace developed 16-17 $\mathrm{kyr}$, which is recognised as the main phase of fluvioperiglacial sedimentation in the Torun-Eberswalde IMV (Tomczak, 1987; Pisarska-Jamroży \& Zieliński, 2011; Weckwerth 2013).

During the maximum extent of the Pomeranian phase, the Torun-Eberswalde IMV collected all waters from sandurs and extraglacial areas; however, a single, common outflow of all waters at the time in the Polish and German parts of the Torun-Eberswalde IMV did not exist. According to Kozarski (1965), waters flowed from the Gorzów and Kostrzyn-Freienwalde Basins southwards to the Warsaw-Berlin IMV (Fig. 1A). A single common outflow of IMV waters did exist in the Torun-Eberswalde IMV during the next subphase, Angermünde-Chojna. All large Pomeranian sandurs (Drawa, Gwda, Brda, Ostróda) functioned during both, i.e., the maximum and Angermünde-Chojna subphases of the Pomeranian phase (Kozarski, 1965), but only two, Drawa and Gwda supplied directly to the part of the Torun-Eberswalde IMV studied here. Sandurs to the west of Drawa sandur (except Myśla sandur) 
hang over ice-marginal terrace (Kozarski, 1965), and were dead during IMV terrace formation. This explains why the sedimentology and heavy mineral spectra at three sites in Pomeranian Drawa and Gwda sandurs (Woliczno, Mielenko and Parsęcko; Fig. 1), have been compared with IMV sites.

In the most westerly part of the Torun-Eberswalde IMV - Eberswalde Valley, as well as in the Polish part of the Torun-Eberswalde IMV, occur four terraces, and the last, tenth site - Macherslust lies on the second terrace (36 $\mathrm{m}$ a.s.1.), the so-called Hauptterrasse, which is correlated with the terrace 40-45 $\mathrm{m}$ a.s.l. in the Gorzów Basin (i.e., the third terrace in the Polish part of IMV). The differences between high terraces in the Gorzów Basin and the Eberswalde Valley were caused by differences in distance between the ice sheet and the IMV. While in the western part of IMV the ice sheet was close to the IMV, in the eastern part the distance between the ice sheet and IMV was significantly greater, which had an influence on terrace development.

Besides sandur supplies, the part of IMV studied here was also fed by extraglacial rivers such as the pre-Warta and pre-Noteć rivers during the Pomeranian phase. Thus, in this context, sediments from one site located in the Poznan Gorge of the Warta River (Mściszewo), connected with the pre-Warta and two in the Inowrocław Plain (Wojdal and Łojewo), connected with the pre-Noteć, were studied (Fig. 1B). All these sites occur on terraces that developed during the Pomeranian phase of Weichselian glaciation.

\section{Methods}

The western and middle part of the Torun-Eberswalde IMV was investigated using detailed sedimentological analysis, heavy mineral analysis, analysis of rounding and frosting of quartz grains and statistical analysis, e.g. Markov chain analysis. Sediments from sites in the Poznan Gorge of the Warta River and the Inowrocław Plain were studied using heavy mineral analysis, and then the spectra obtained were compared with previous work on sandur sites and with IMV spectra (e.g. Pisarska-Jamroży et al., in press $\mathrm{a}, \mathrm{b}$ ).

In sedimentological analyses, grain size terminology follows the Udden-Wentworth scale (Udden, 1914; Wentworth, 1922). Lithofacies and architectural elements are coded following Miall (1978), and some additional lithofacies codes and architectural elements (Table 1A, B) were added, following Zieliński and Pisarska-Jamroży (2012). Additionally, maximum particle size (MPS) was calculated on the basis of the ten largest grains in all gravelly and in sandy lithofacies (which contain gravels scattered within sands). Some sedimentological results from the proximal part of the Drawa sandur (Pisarska-Jamroży \& Zieliński, 2014), the Middle Noteć Valley (Pisarska-Jamroży \& Zieliński, 2011; Weckwerth \& Pisarska-Jamroży, in press), the Eberswalde Valley (Pisarska-Jamroży, 2013) have been published previously. In the present paper new sedimentological evidence from new sandur sites

Table 1. Codes used in sedimentary logs. A: Lithofacies codes (with explanation of codes regarding texture and structure of sediments as proposed by Miall, 1978, and Zieliński \& Pisarska-Jamroży, 2012). B: Architectural elements (Zieliński \& Pisarska-Jamroży, 2012). C: Symbols used in Figs 2, 4 and 6.

\begin{tabular}{|c|c|c|c|}
\hline A] & \multicolumn{2}{|c|}{ Lithofacies code } & \multirow{3}{*}{$\begin{array}{l}\text { Architectural elements } \\
\text { code } \\
\text { Bed-, channel form or } \\
\text { type of deposition }\end{array}$} \\
\hline Symbol & Grain size & Structure & \\
\hline \multirow{2}{*}{ Breccia } & \multirow{2}{*}{$\begin{array}{l}\text { clasts from } \mathrm{mm} \\
\text { to } \mathrm{m}\end{array}$} & \multirow{2}{*}{$\begin{array}{l}\text { massive or planar cross- } \\
\text { stratification }\end{array}$} & \\
\hline & & & GB gravelly bedform \\
\hline $\mathrm{DGm}$ & gravelly diamicton & massive & SB sandy bedform \\
\hline Gt & gravel & trough cross-stratification & \multirow[t]{2}{*}{$F M$ transverse bar } \\
\hline GSt & sandy gravel & trough cross-stratification & \\
\hline $\begin{array}{l}\text { SGt } \\
\text { SGp }\end{array}$ & gravelly sand & $\begin{array}{l}\text { trough cross-stratification } \\
\text { planar cross-stratification }\end{array}$ & SG sediment gravity flow \\
\hline $\mathrm{Sm}$ & \multirow{6}{*}{ sand } & \multirow{6}{*}{$\begin{array}{l}\text { massive } \\
\text { horizontal stratification } \\
\text { low-angle planar cross- } \\
\text { stratification } \\
\text { trough cross-stratification } \\
\text { planar cross-stratification } \\
\text { climbing ripple cross- } \\
\text { lamination }\end{array}$} & Key to lithofacies log \\
\hline Sh & & & \\
\hline SI & & & def. deformed deposit \\
\hline St & & & $\Rightarrow z$ normal \& reverse faults \\
\hline $\mathrm{Sp}$ & & & $\Im$ fold \\
\hline Src & & & es load structures \\
\hline FSh & sandy fines* & horizontal lamination & \multirow{3}{*}{$\begin{array}{ll}{ }_{20}^{\mathrm{MPS}} & \text { maximum particle size } \\
{[\mathrm{mm}]}\end{array}$} \\
\hline Th & silt & horizontal lamination & \\
\hline $\mathrm{Mh}$ & clay & horizontal lamination & \\
\hline
\end{tabular}


as well as new, unpublished IMV sites are presented and discussed in the context of previous studies.

The heavy mineral analysis was performed on grains of fine sand fraction $(0.125-0.25 \mathrm{~mm})$, covering high-density grains representing the detrital occurrence of essential rock-forming minerals (e.g. garnet, pyroxenes, biotite, muscovite) and accessories (e.g. zircon, tourmaline) with densities $>2.8$ $\mathrm{gcm}^{-3}$; thus they are termed 'heavy minerals' (Mange \& Maurer, 1992). The samples were taken from the defined lithofacies. The percentage of each heavy mineral was determined by counting 300-2100 (700 on average) grains (transparent and opaque) per slide. All percentages were subsequently calculated with respect to the sum of all transparent, plus all opaque heavy minerals. The non-transparent minerals were identified by their optical and macroscopical features under a petrographic microscope and binocular. Further, the transparent/opaque ratio (T/O) was calculated. A coefficient was calculated, based on the relationship between amphibole and garnet, following Marcinkowski (2007), weathering index (W index) was calculated from the equation of Racinowski and Rzechowski (1969), W = (St/T) $\mathrm{N}$, where $\mathrm{T}$ is the percentage of stable minerals that are resistant to abrasion (zircon, rutile, tourmaline, staurolite, kyanite) if the total of transparent heavy minerals is taken as $100 \%$; St is the percentage of medium-resistant minerals (epidote, garnet, sillimanite), and $\mathrm{N}$ is the percentage of non-resistant minerals (amphibole, pyroxene, biotite, chlorite). The higher the weathering index, the more weathered a sediment is or a sediment was enriched (e.g. in effect of erosional processes) by weathered minerals. All heavy minerals samples were sampled from fresh non-weathered walls in outcrops. Also in case of heavy mineral analysis, some results from sediments in sandurs and IMV sites have been published previously (Pisarska-Jamroży et al., in press $\mathrm{a}, \mathrm{b})$. The present paper contains new results that are discussed in the context of previous studies.

The rounding and frosting of quartz grains were examined using the Mycielska-Dowgiałło and Woronko (1998) method. Over 150 quartz grains of the sandy fraction $(0.8-1 \mathrm{~mm})$ were counted in each of 48 samples derived from the proximal parts of the Drawa and Gwda sandurs and terrace sediments of the Torun-Eberswalde IMV. Four rounding and frosting classes of quartz grains were distinguished: (1) aeolian, very well and moderately rounded, (2) fluvial very well and moderately rounded, (3) broken and angular grains, and (4) other grains (Table 2).

In addition, a Markov chain statistical analysis was applied in order to establish the most frequent sedimentary successions (see Cant \& Walker, 1976; Miall, 1977) in IMV and the results were compared with the sandur sedimentary cyclicity as described by Pisarska-Jamroży \& Zieliński (2014). The Markov chain analysis was used also in investigations of glaciolimnic succession in Eberswalde Valley (Pisarska-Jamroży, 2013), which is discussed in the context of present paper.

Palaeohydraulic parameters which allowed to characterise and interpret the depositional environment of fluvial sediments were calculated for part of IMV studied. Palaeoflow calculations (Table 3) include flow velocity, bed shear stress (Williams, 1983), flow power (Bagnold, 1966), flow depth estimated on the basis of lithofacies thickness (Friend \& Moody-Stuart, 1972; Klimek, 1972; Saunderson \& Jopling, 1980; Bridge, 2003), and mean Froude number (Fr) calculated for three divided zones in IMV braided river system and for the upper and middle part of lower flow regime. Estimation of flow depth was not possible for lithofacies with low-angle planar cross-stratified sandy lithofacies (Sl) and it was omitted in calculations, because lithofacies Sl developed due to flattened and washed-out bars and estimation of flow depth in this case is impossible. All formulas presented in Table 3 generally are used for gravel-bed rivers and their gravel lithofacies (Williams, 1983), but in the case of IMV succession, they were used for sandbed rivers too and their sandy lithofacies, which in IMV contain gravels scattered within sands, so MPS measurements necessary to formula calculation were available. The stream power which carried sands with an admixture of gravels was strong enough to transport larger particles such as gravels implying that the calculation procedure is correct. The use of Williams (1983) formulas to the palae-

Table 2. Distribution of average percentages of quartz grain classes in the Pomeranian sandurs and the Torun-Eberswalde ice-marginal valley.

\begin{tabular}{|lcc|}
\hline \multicolumn{3}{|c|}{ Percentages of quartz grain classes } \\
\hline Quartz grain class & $\begin{array}{c}\text { Sandur } \\
\text { sediments }\end{array}$ & $\begin{array}{c}\text { IMV } \\
\text { sediments }\end{array}$ \\
\hline $\begin{array}{l}\text { fluvial grains very well } \\
\text { \& moderately rounded }\end{array}$ & 83.2 & 86.8 \\
$\begin{array}{l}\text { aeolian grains very } \\
\text { well \& moderately } \\
\text { rounded }\end{array}$ & 4.0 & 2.7 \\
$\begin{array}{l}\text { broken \& angular } \\
\text { grains }\end{array}$ & 6.6 & 5.3 \\
\hline other grains & 6.3 & 5.2 \\
\hline
\end{tabular}


ohydraulic parameter calculations meant that the Manning coefficient of roughness was not taken into consideration in calculations. The Manning coefficient of roughness arises as a result of bed forms and channel form development, so there is a risk that the results will be overestimated. However, Williams formulas (1983) based on the parameter MPS (Table 3) are underestimated due to the limited extent of outcrop in IMV; some larger gravels can be omitted and it is unlikely that in outcrop clasts the largest clasts representative of the whole lithofacies occur. Therefore, it can be concluded that estimates resulting from Williams (1983) formulas are not overestimated. Moreover, formulas using the Manning coefficient of roughness need hydraulic gradient estimated approximately on the basis of slope terrace (e.g. Manning formula of mean velocity). The slope terrace yields only approximate information on the hydraulic gradient and significantly changes results of velocity calculations (Manning formula of mean velocity), even with small changes in slope terrace (and thus can lead to potential error in calculations).

Table 3. Palaeohydraulic parameters used in calculations in the studied part of the Torun-Eberswalde ice-marginal valley.

\begin{tabular}{|c|c|}
\hline \multicolumn{2}{|c|}{ Palaeohydraulic parameters } \\
\hline Formula & Description \\
\hline$\omega_{t}=\tau V \quad\left[\mathrm{Wm}^{-2}\right]$ & $\begin{array}{l}\text { flow power } \\
\text { (Bagnold, 1966) }\end{array}$ \\
\hline $\mathrm{V}=\left(\mathrm{V}_{1}+\mathrm{V}_{2}\right) / 2\left[\mathrm{~ms}^{-1}\right]$ & $\begin{array}{l}\text { mean flow velocity } \\
\text { (Williams, 1983) }\end{array}$ \\
\hline \multicolumn{2}{|l|}{$\mathrm{V}_{1}=0.065 \mathrm{MPS}^{0.5}\left[\mathrm{~ms}^{-1}\right]$} \\
\hline \multicolumn{2}{|l|}{$\mathrm{V}_{2}=0.46 \mathrm{MPS}^{0.5}\left[\mathrm{~ms}^{-1}\right]$} \\
\hline$\tau=\left(\tau_{1}+\tau_{2}\right) / 2\left[\mathrm{Nm}^{-2}=\mathrm{Pa}\right]$ & $\begin{array}{l}\text { bed shear stress } \\
\text { (Williams, 1983) }\end{array}$ \\
\hline \multirow{2}{*}{\multicolumn{2}{|c|}{$\begin{array}{ll}\tau_{1}=3.9 \mathrm{MPS} & {\left[\mathrm{Nm}^{-2}\right]} \\
\tau_{2}=0.17 \mathrm{MPS} & {\left[\mathrm{Nm}^{-2}\right]}\end{array}$}} \\
\hline & \\
\hline $\mathrm{D} \quad[\mathrm{m}]$ & $\begin{array}{l}\text { flow depth estimated on } \\
\text { the base: }\end{array}$ \\
\hline $\mathrm{D} \sim \mathrm{h}_{1} \quad[\mathrm{~m}]$ & $\begin{array}{l}\text { bar height }\left(h_{1}\right) \sim \text { thickness } \\
\text { of lithofacies Sp, SGp } \\
\text { (Friend \& Moody-Stuart, 1972; } \\
\text { Klimek, 1972; Saunderson \& } \\
\text { Jopling, 1980) }\end{array}$ \\
\hline $\mathrm{D}=3 \mathrm{~h}_{2} \quad[\mathrm{~m}]$ & $\begin{array}{l}\text { trough depth }\left(h_{2}\right) \sim \text { thickness } \\
\text { of lithofacies St, SGt, GSt, Gt } \\
\text { (Bridge, 2003) }\end{array}$ \\
\hline$F=V(g D)^{-0.5}$ & Froude number \\
\hline & gravity acceleration (g) \\
\hline
\end{tabular}

\section{Sediment source areas in IMV}

Sediments found in the Torun-Eberswalde IMV are a combination of deposits derived from the northern sources of the Weichselian ice-sheet, from the eroded substratum of the Torun-Eberswalde IMV (Pisarska-Jamroży et al., in press a) and from the southern sources of main rivers such as pre-Warta and pre-Noteć.

\subsection{Proglacial feeding of IMV}

The contribution of sediments derived from proglacial streams in IMV was established on the basis of heavy mineral spectra from proximal parts of the Drawa and Gwda sandur sediments and from the Torun-Eberswalde IMV terrace (Pisarska-Jamroży et al., in press a). The heavy mineral analysis shows that there are no significant differences in heavy mineral composition between the sandurs and IMV sediments (Pisarska-Jamroży et al., in press a), in that all are dominated by amphibole, limonite, the opaque mineral rest group (magnetite, other iron oxides), garnet, epidote and biotite (Table 4). The slight differences that occur between sandurs and IMV sediments are described in section 4.2 below. Comparable heavy mineral spectra in the sandurs and IMV, a predominance of amphibole and garnet, and comparable A-coefficients suggest the same mineral source, i.e. the Palaeozoic and Precambrian rocks in the East Central Baltic (compare Passchier, 2007). Differences between sandur and IMV sediments are seen in the weathering index, which is lower in sandurs than in IMV (Table 4).

No significant differences occur either in the rounding and frosting of quartz grains from sandurs and from IMV. Sandur and IMV sediments are dominated by fluvial origin grains (Table 3). Although such grains were developed partially at least in a fluvial environment, it is difficult to interpret them as having formed in glaciofluvial or fluvial environments on the Drawa and Gwda sandurs or in the Torun-Eberswalde IMV, but rather they come from older eroded deposits. The distance of glaciofluvial transport on the Drawa and Gwda sandurs was not large enough to change the rounding of quartz grains $(1-5 \mathrm{~km}$ from end moraine of Pomeranian phase to the sites of proximal parts of sandurs studied). The distance of fluvial transport in the Torun-Eberswalde IMV was larger, which caused a slightly better rounding of quartz grains, but still not large enough to change significantly the rounding of grains $(90 \mathrm{~km}$ between Rozwarzyn 
Table 4. Spectra of heavy minerals from the Pomeranian sandurs, the studied part of the Torun-Eberswalde ice-marginal valley, the Pleistocene substratum of the IMV, and the pre-Warta river and pre-Noteć rivers (Pisarska-Jamroży et al., in press a, supplemented).

\begin{tabular}{|c|c|c|c|c|c|}
\hline \multicolumn{6}{|c|}{ Heavy mineral composition [\%] } \\
\hline $\begin{array}{c}\text { Heavy minerals/ } \\
\text { coefficients }\end{array}$ & $\begin{array}{c}\text { Sandur } \\
\text { sediments }\end{array}$ & $\begin{array}{c}\text { IMV } \\
\text { sediments }\end{array}$ & $\begin{array}{l}\text { Pleistocene } \\
\text { substatum }\end{array}$ & $\begin{array}{l}\text { Pre-Warta } \\
\text { sediments }\end{array}$ & $\begin{array}{l}\text { Pre-Noteć } \\
\text { sediments }\end{array}$ \\
\hline transparent & 58.2 & 65.5 & 58.4 & 56.7 & 71.9 \\
\hline andalusite & 0 & 0 & 0.2 & 0.1 & 0 \\
\hline rutile & 1.0 & 0.8 & 1.2 & 0.4 & 1.7 \\
\hline zircon & 1.4 & 1.1 & 2.2 & 1.9 & 3.8 \\
\hline kyanite & 0.7 & 0.5 & 0.9 & 0.4 & 0.6 \\
\hline staurolite & 0.7 & 1.1 & 1.7 & 1.3 & 0.8 \\
\hline tourmaline & 1.1 & 1.1 & 2.5 & 0.8 & 1.2 \\
\hline clinozoisite & 1.9 & 2.0 & 2.1 & 0.6 & 3.1 \\
\hline epidote & 7.4 & 5.8 & 5.3 & 7.1 & 11.6 \\
\hline garnet & 12.4 & 13.5 & 14.0 & 21.9 & 12.3 \\
\hline sillimanite & 0.6 & 0.5 & 0.9 & 0.5 & 0.5 \\
\hline amphibole & 20.9 & 22.6 & 16.0 & 15.3 & 27.2 \\
\hline othopyroxene & 0.2 & 0.4 & 0.1 & 0.7 & 0.2 \\
\hline clinopyroxene & 1.2 & 1.9 & 1.7 & 1.0 & 1.3 \\
\hline glauconite & 0.3 & 1.3 & 1.6 & 1.8 & 1.0 \\
\hline muscovite & 0.3 & 0.3 & 1.2 & 0.1 & 2.8 \\
\hline biotite & 1.6 & 4.1 & 6.3 & 3.0 & 2.1 \\
\hline chlorite & 0.2 & 0.3 & 0.3 & 0.1 & 1.7 \\
\hline opaque & 41.8 & 34.5 & 41.6 & 43.3 & 28.1 \\
\hline limonite & 18.0 & 23.8 & 26.9 & 15.0 & 4.3 \\
\hline pyrite & 0 & 0 & 0.1 & 0.3 & 1.0 \\
\hline $\begin{array}{l}\text { opaque rest } \\
\text { group* }\end{array}$ & 23.8 & 11.7 & 14.7 & 28.0 & 23.0 \\
\hline $\mathrm{T} / \mathrm{O}$ ratio & 1.4 & 1.9 & 1.5 & 1.3 & 2.5 \\
\hline A-coefficient & 1.5 & 1.9 & 1.3 & 1.6 & 2.2 \\
\hline W index & 161 & 212 & 148 & 223 & 134 \\
\hline
\end{tabular}

and Zwierzyn, see Fig. 1B). Experimental studies on the influence of fluvial transport on quartz grain surfaces have shown that changes of roundness develop extremely slowly (Lindé \& Mycielska-Dowgiałło, 1980). Woronko et al. (2013) claimed that after 750 hours of fluvial transport simulation quartz grain surfaces became shiny, but roundness did not change significantly.

Summarizing, the heavy mineral spectra and contribution of quartz grains classes from both the Drawa and Gwda sandurs and from the Torun-Eberswalde IMV sediments are closely similar, which suggests that the IMV was mainly supplied by sandur rivers.

\subsection{Pleistocene substratum as sediment source in IMV}

Outcrops of IMV substratum containing older, often glaciotectonically elevated, Miocene/Pliocene sediments (Gadomska, 1957; Szupryczyński, 1958; Schlaak, 1993; Bartczak, 2006), as well as older Pleistocene glaciogenic and interglacial sediments had an impact on the mineral composition of the terrace sediments (Pisarska-Jamroży et al., in press a). Glacioisostatic movements after deglaciation of IMV area and its surroundings (= during the Pomeranian phase; Niewiarowski, 1983; Liszkowski, 1992, 1993; Weckwerth, 2013) played also a role in the mineral composition of IMV terraces sediments. The braided river in the Torun-Eberswalde IMV eroded substratum sediments. Outcrops of Miocene and Pliocene sediments are known from the literature (Gadomska, 1957; Szupryczyński, 1958; Kozarski, 1959; Bartczak, 2006), namely in the vicinity of Dębowa Góra in the northern part of the Middle Noteć Valley, in the mouth of the Gwda River to the Noteć River, in the northern part of the Ujście Basin, in the eastern part of the Gorzów Basin (Fig. 1) and in the northern part of the Torun Basin (Weckwerth, 2013). Differences in heavy mineral spectra between the Torun-Eberswalde IMV terrace and the Pleistocene substratum sediments (Table 4) are generally slight and can be explained by fluvial erosion of older sediments in IMV, and enriched terrace sediments from eroded substratum zircon, staurolite, tourmaline, glauconite, biotite and limonite (Pisarska-Jamroży 
et al., in press a). The Pleistocene and Miocene/Pliocene substratum could have contributed almost all these minerals, but it is possible that some of them, e.g. zircon, could have been supplied by sandurs.

Glauconite in IMV terraces probably derives from the Miocene sediments which contain reworked glauconite (Bartczak, 2006; Widera, 2007). Limonite in IMV terraces may also have originated from Miocene deposits or could have developed in diagenetic processes in water-saturated sediments which led to alteration of some minerals to limonite. This process is more effective in higher porosity gravels than in sands, because water content in gravels exceeds that in sands (Pisarska-Jamroży et al., in press b).

Known from the substratum are also very well-rounded quartz grains with shiny and smooth surfaces, interpreted as grains of a fluvial origin. These grains may derive from Miocene/Pliocene sediments (Galon, 1961), or from Eemian fluvial sediments noted in the eastern part of the Torun-Eberswalde IMV by Weckwerth \& Chabowski (2013) and Weckwerth (2013).

Summarizing, some heavy minerals such as zircon, staurolite, tourmaline, glauconite, biotite and limonite, as well as very well-rounded fluvial quartz grains, may indicate the erosional origin of terrace sediments. They can be derived from Miocene/Pliocene as well as from Pleistocene sediments, e.g. Eemian fluvial deposits.

\subsection{Extraglacial feeding of IMV}

Extraglacial rivers from the south (e.g. pre-Noteć and pre-Warta rivers) and proglacial rivers from the north had several different catchment areas, but their sediments are dominated by amphibole, garnet, epidote, biotite, limonite and other opaque minerals (Table 4). The heavy mineral composition may be explained by the fact that the extraglacial rivers eroded sediments of glaciations older than the Weichselian as well as interglacial sediments. Older glacial sediments had similar northerly sources as during the Pomeranian phase of the Weichselian glaciation. Additionally, the long distance from the southern part of the catchment area (which can contain specific spectra of heavy minerals e.g. from the Kraków-Częstochowa Upland) of extraglacial rivers to the Torun-Eberswalde IMV could have caused abrasion of some minerals. The length of the Warta River from the source in the Kraków-Częstochowa Upland in southern Poland to Oborniki (southern boundary of IMV) is $603 \mathrm{~km}$. The length of the Noteć River from the source in Kujawy Lakeland in central
Poland to the mouth of the Warta River in IMV is $391 \mathrm{~km}$. The next possibility is that sediment supply by extraglacial rivers was minimal (see Pisarska-Jamroży et al., in press a).

Heavy mineral spectra from the pre-Noteć River (Fig. 1B; Table 4) reveal a higher percentage of epidote $(11.6 \%)$. The pre-Noteć River sediments contain the highest percentage, among all sites analysed, of amphibole (27.2\%), muscovite (2.8\%), chlorite $(1.7 \%)$, zircon $(3.8 \%)$ and rutile $(1.7 \%)$, and the lowest percentage of limonite $(4.3 \%)$. The source area of the Noteć River is not southern, but central Poland, so that all these minerals may have originated mainly from eroded Pleistocene substratum. The weathering index of the pre-Noteć River terrace reaches only 134 (similar to the Pleistocene substratum - 148, and Pomeranian sandur sediments 161). This could have been caused by redeposition processes of previously deposited sediments by the pre-Noteć River, but this requires more research.

Heavy mineral spectra from the pre-Warta River terrace sediments (Fig. 1B; Table 4) have a slightly higher percentage of epidote than in IMV sites. The pre-Warta terrace sediments contain the highest percentages of garnet $(21.9 \%)$, and the highest percentage of other opaque minerals (28\%), of all sites analysed. On the one hand, the epidote and garnet could have been derived from southern sources of the pre-Warta River, and on the other from the Pleistocene catchment area of the pre-Warta River. The pre-Warta terrace sediments are characterised by a high value of weathering index (223), similar to IMV sediments (212).

\subsection{Distribution of heavy minerals in part of IMV studied}

Additionally, heavy mineral grains undergo sorting in a fluvial environment as a result of differences in density, shape and size (cf. Steidtmann, 1982; Komar, 2007; Van Loon, 2013), and the relative proportions of the various heavy minerals vary with transport distance (see Van Andel, 1950; Lowright et al., 1972; Van Loon, 1973). Changes (in percentages) of heavy minerals with distance from Rozwarzyn to Zwierzyn (Fig. 1B) are clear in the study area for biotite and amphibole. Amphibole increases slightly from east to west (= downstream) as does the $\mathrm{T} / \mathrm{O}$ ratio. The reverse tendency occurs with biotite because of intensive mechanical abrasion during transport: its percentage decreases westwards (Fig. 1B).

Analysis of heavy minerals in the separate gravelly and sandy lithofacies shows also an interesting 
relationship: the less-resistant heavy minerals (e.g. biotite) occur much more frequently in gravels than in sands. In the flow-transported gravels platy minerals were carried mainly in suspension, whereas those in the flow-transported sands were carried mainly through saltation and traction, during which mechanical destruction processes of less-resistant heavy minerals are more common than in flow-transported gravels. All these changes must be ascribed to sorting processes by glaciofluvial/fluvial transport (Pisarska-Jamroży et al., in press b).

\section{Depositional mechanisms controlling Toruń-Eberswalde IMV sedimentation}

In ten sites of the Torun-Eberswalde IMV detailed sedimentological analyses were carried out (Fig. 1B). In nine out of ten (Rudnica, Brzozowiec, Zwierzyn, Łącznica, Nowe Dwory, Kuźnica Czarnkowska, Walkowice, Atanazyn and Rozwarzyn; Figs 3, 4 and 5) occur fluvial sedimentary successions (see section 5.2), and at one - Macherslust (Fig. 2) - a glaciolimnic succession (see section 5.1).

\subsection{Glaciolimnic sedimentation in IMV - initial phase of IMV development}

A specific kind of sedimentary succession was recognised in the western part of the Torun-Eberswalde IMV near Eberswalde in Macherslust (see Pisarska-Jamroży, 2013). The succession (Fig. 2) is composed of silts with horizontal lamination (lithofacies Th) with, additionally, a horizontally laminated clay (lithofacies Mh); less common are finegrained, massive and horizontally laminated sands (lithofacies Sm, Sh). The boundaries of the silty, clayey and sandy lithofacies are mostly sharp but non-erosional. A characteristic feature is the rhythmic nature of the succession, which forms couplets of $\mathrm{Th} \rightarrow \mathrm{Mh}$ (up to $45 \mathrm{~cm}$ thick megavarves), and less common of $\mathrm{Sh} \rightarrow \mathrm{Mh}$ and of $\mathrm{Sm} \rightarrow \mathrm{Mh}$ (Fig. 2). The typical thickness of a 'classic' varve varies between 0.2 and $100 \mathrm{~mm}$; average: $20-50 \mathrm{~mm}$ (see Ashley, 1975; Gilbert, 1975; Brodzikowski \& Van Loon, 1980; Hasholt, 1995). The unusually thick silty summer layers (Th lithofacies) derived from suspended particles supplied to the lake by cyclic (typically in ablation supply) and dense meltwater currents - hyperconcentrated flows (Pisarska-Jamroży, 2013). Hyperconcentrated flow conditions have been identified in association with high magnitude floods in the proglacial sedimentary record

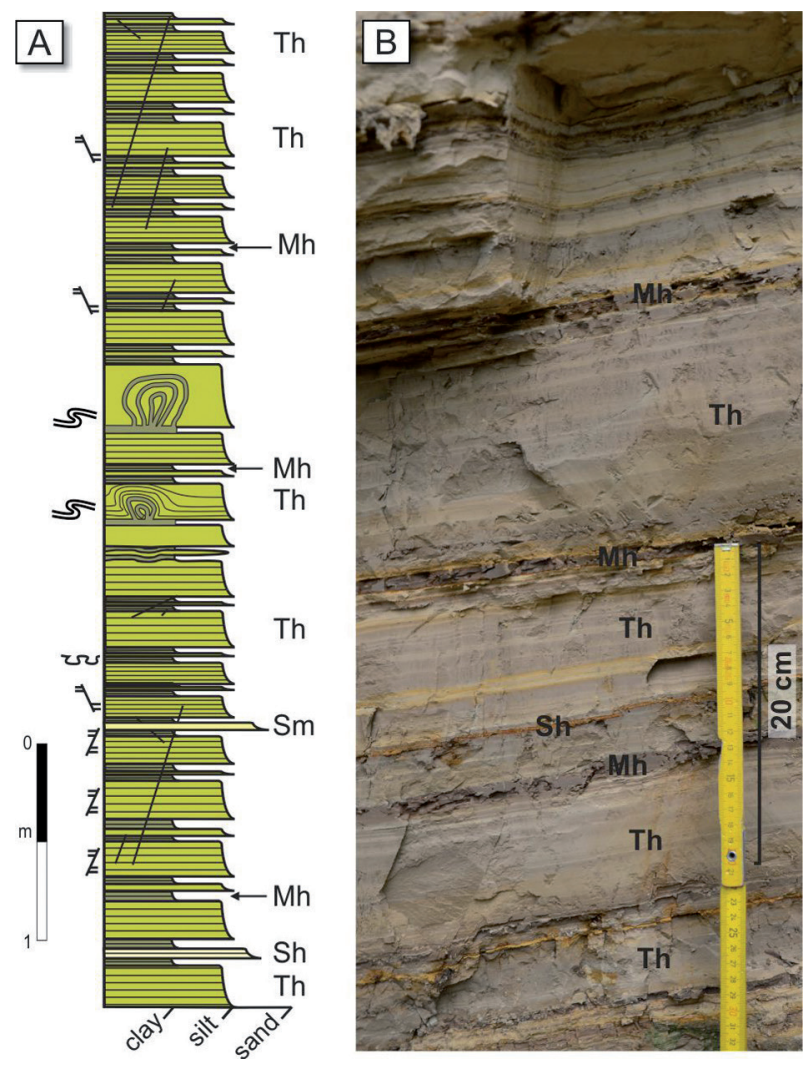

Fig. 2. Megavarves at Macherslust (Eberswalde Valley) A - Schematic sedimentary log; B - Part of Macherslust succession showing vertical lithofacies distribution. For explanation see Table 1.

(Marren, 2005). Deposits of hyperconcentrated flows on sandurs are known from glaciomarginal areas (Plink-Björklund \& Ronnert, 1999; Pisarska-Jamroży, 2006, 2007, 2008a, b). The occurrence of silty-clayey megavarves in the Torun-Eberswalde IMV sediments indicates the proglacial, northern source of sediments, but such is very rare and recorded in specific morphological conditions, just as in the Eberswalde Valley; the megavarves were deposited in older depressions of atypically oriented subglacial tunnel valleys, semi-parallel to the axis of the Torun-Eberswalde IMV (ENEWSW). Such tunnel valleys were recognised by Börner (2007). Otherwise an N-S oriented valley incision, from the ice-sheet to the IMV, supplied hyperconcentrated flow to IMV (Pisarska-Jamroży, 2013). The hyperconcentrated inflow at Macherslust probably contained mainly silt with an admixture of clay, resulting in a fairly homogeneous grain size of the silty lithofacies (Pisarska-Jamroży, 2013). The megavarves were deposited from suspended particles supplied to the lake by cyclic and dense meltwater currents. Megavarves at Macherslust, deposited by dense hyperconcentrated flows in a quite deep lake in tunnel valley, supports bad- 
(2) deep sand-bed braided channel zone with transverse bars

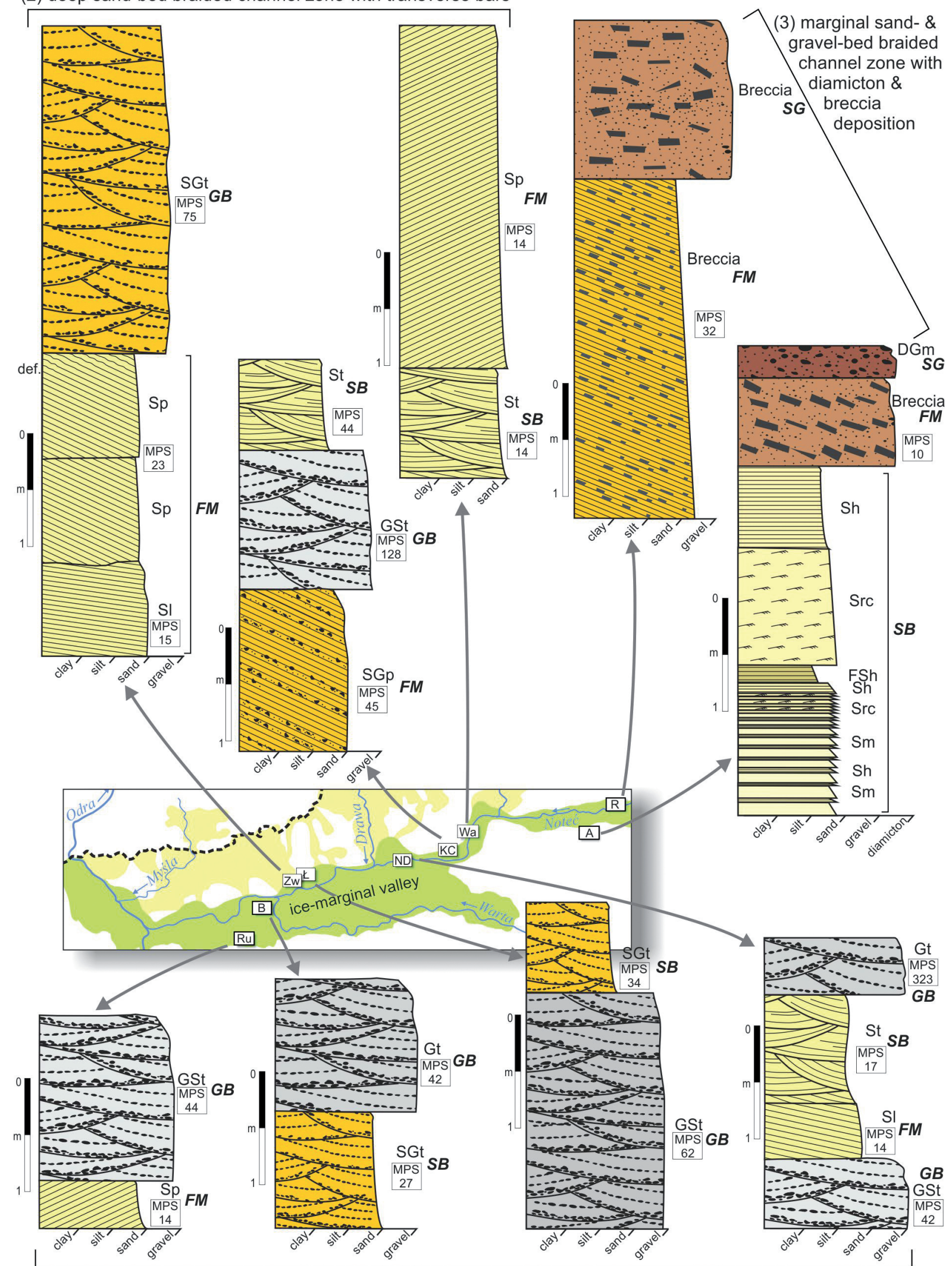

(1) deep gravel-bed braided channel zone with extensive scours

Fig. 3. Schematic sedimentary logs with lithofacies and environmental architectural elements in fluvial successions of the Torun-Eberswalde ice-marginal valley sites. For explanation see Table 1. 

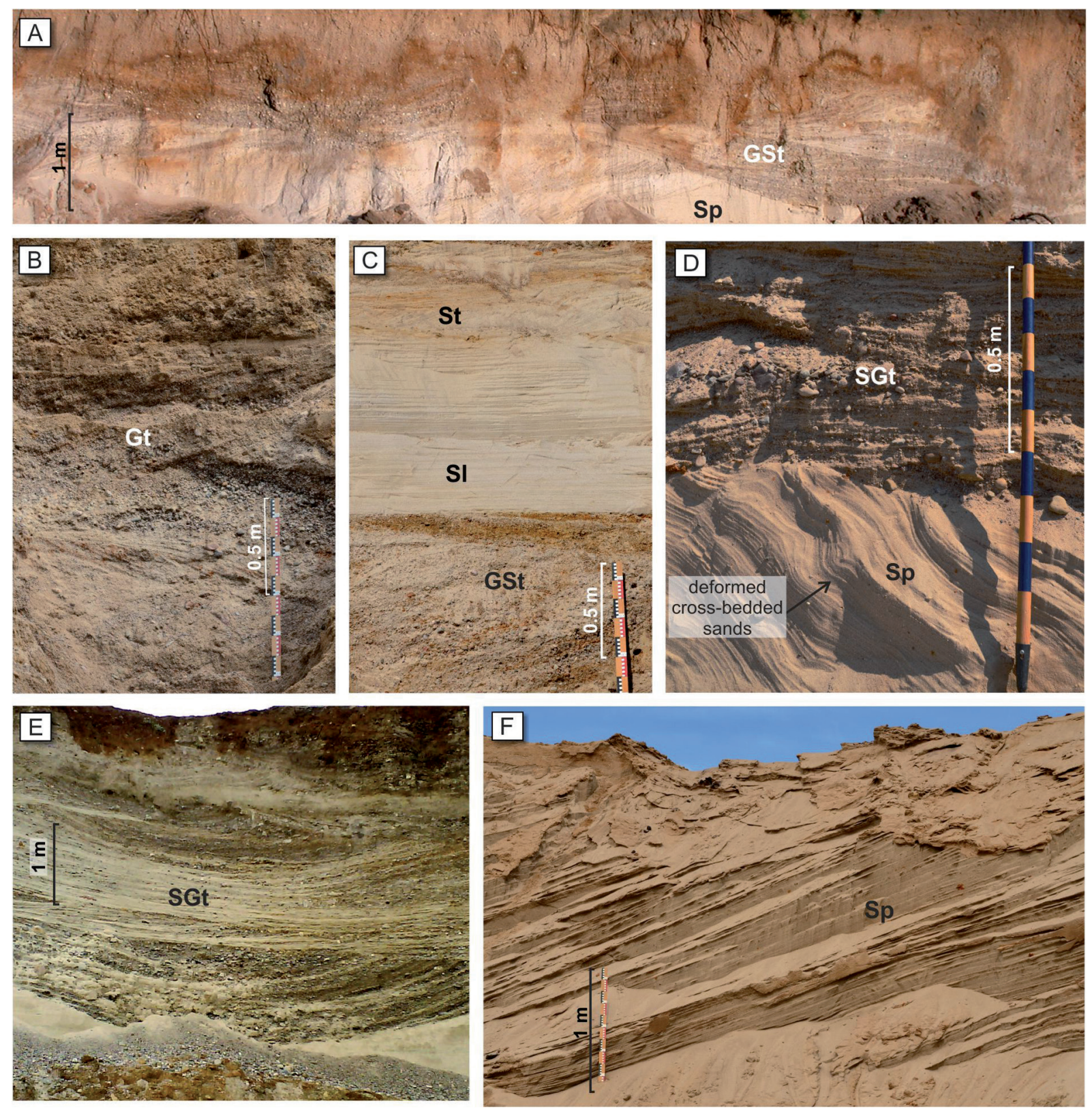

Fig. 4. Sedimentary details of fluvial successions in the Torun-Eberswalde ice-marginal valley derived from deep gravel-bed braided channel zone with extensive scours and deep sand-bed braided channel zone with transverse bars. A - Planar and trough cross-stratified gravelly sands and sands at Brzozowiec site; B - Trough cross-stratified gravels at Łącznica site; C - Trough cross-stratified sandy gravels, low-angle planar cross-stratified sands and trough cross-stratified sands at Nowe Dwory site; D - Deformed cross-bedded laminae in planar-cross-stratified lithofacies at Zwierzyn site; E - Major channels of the Torun-Eberswalde ice-marginal valley at Zwierzyn site; F - Large-scale planar cross-stratified sands at Walkowice site.

ly bleached sediments (OSL ages: $14.6 \pm 6.5 \mathrm{kyr}$ and $12.18 \pm 4.5$ kyr; Pisarska-Jamroży, 2013). The glaciolimnic succession (megavarves) was subsequently eroded by braided river currents in IMV, leaving some erosional remnants which formed common, morphologically positive elements in the valley (Pisarska-Jamroży, 2013).

\subsection{Braided river system in IMV}

The sedimentary successions from nine sites (Fig. 3) in IMV were grouped into three zones (sections 5.2.1-5.2.3) with regard to their main depositional conditions, architectural elements and palaeohydraulic parameters: (1) deep gravel-bed braided 

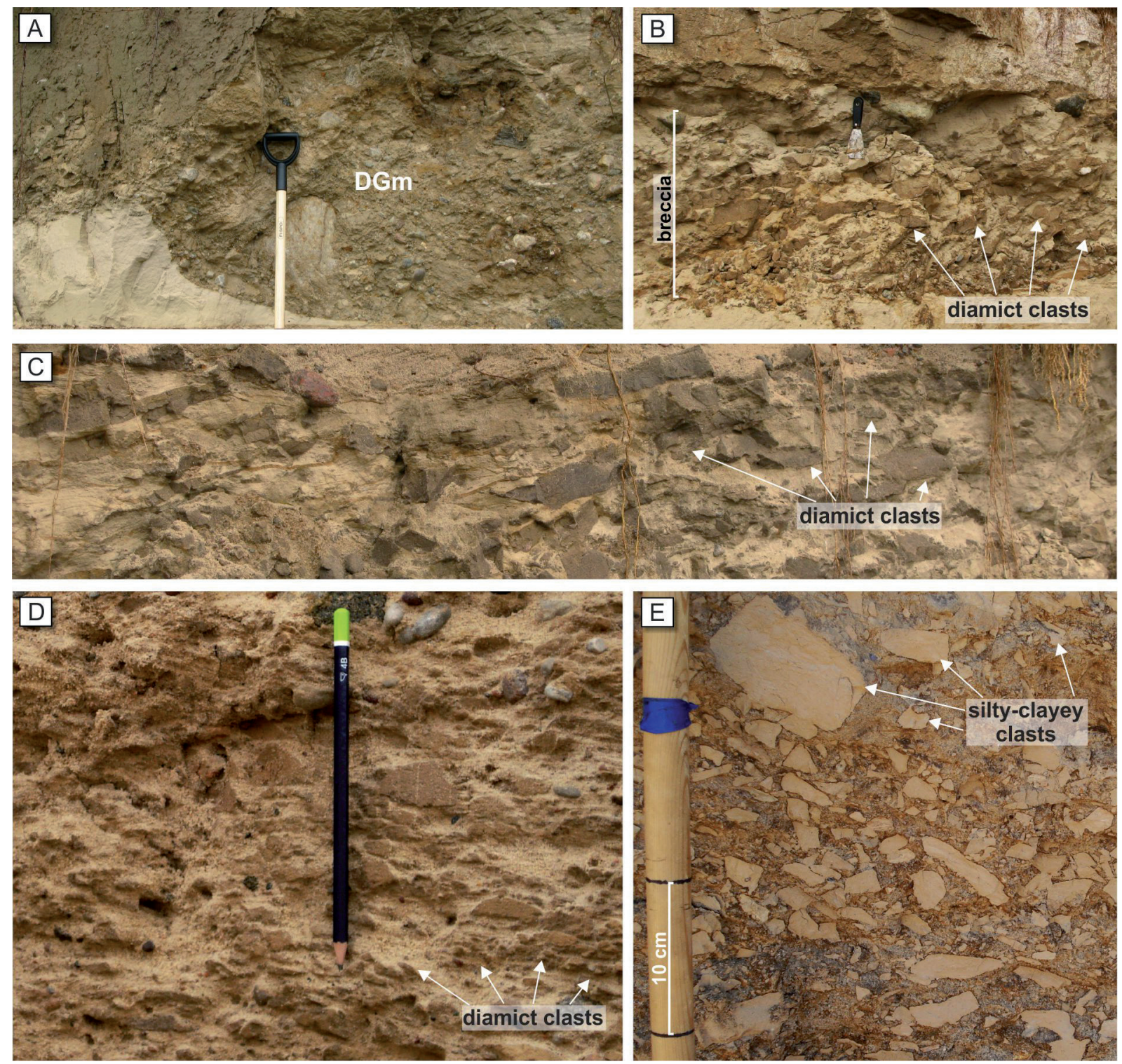

Fig. 5. Sedimentary details of fluvial successions in the Torun-Eberswalde ice-marginal valley derived from marginal sand- and gravel-bed braided channel zone with diamicton and breccia deposition.

A - Massive gravelly diamicton of debris-flow origin at Atanazyn; B - Fluvial breccia at Atanazyn site; C - Imbricated diamict clasts in breccia at Atanazyn site; D - Fluvial breccia at Rozwarzyn; E - Debris-flow breccia at Rozwarzyn.

channel zone with extensive scours, (2) deep sandbed braided channel zone with transverse bars, and (3) marginal sand-bed and gravel-bed braided channel zone with diamicton and breccia deposition (Figs 6 and 7). In each of the sequences cyclicity in vertical lithofacies succession (on the basis of Markov chain analysis) was analysed. Results thus obtained were statistically irrelevant - the probability of transitions of lithofacies ' $x$ ' dominating over lithofacies ' $y$ ' was close to zero. In the case of IMV sediments occur some limitations for Markov chain analysis usage, such as insufficiently long sedimentological sequences at outcrop. Depositional cyclicity is well known from sandur sediments, lacustrine and glaciolacustrine sediments and the Markov chain were used e.g. by Fraser (1982) and Pisarska-Jamroży \& Zieliński (2014), but depositional cyclicity did not occur in sediments studied in Torun-Eberswalde IMV.

\subsubsection{Deep gravel-bed braided channels zone with extensive scours}

At four sites (Rudnica, Brzozowiec, Łącznica and Nowe Dwory; Fig. 1B) occur mainly gravelly, sandy-gravelly and gravelly-sandy, trough-shaped sets (lithofacies Gt, GSt, SGt, St) up to $2.5 \mathrm{~m}$ (on average $0.5 \mathrm{~m}$ ) thick and up to $1.5 \mathrm{~m}$ wide (Figs 3 and 4 ). The troughs in sandy sediments generally 

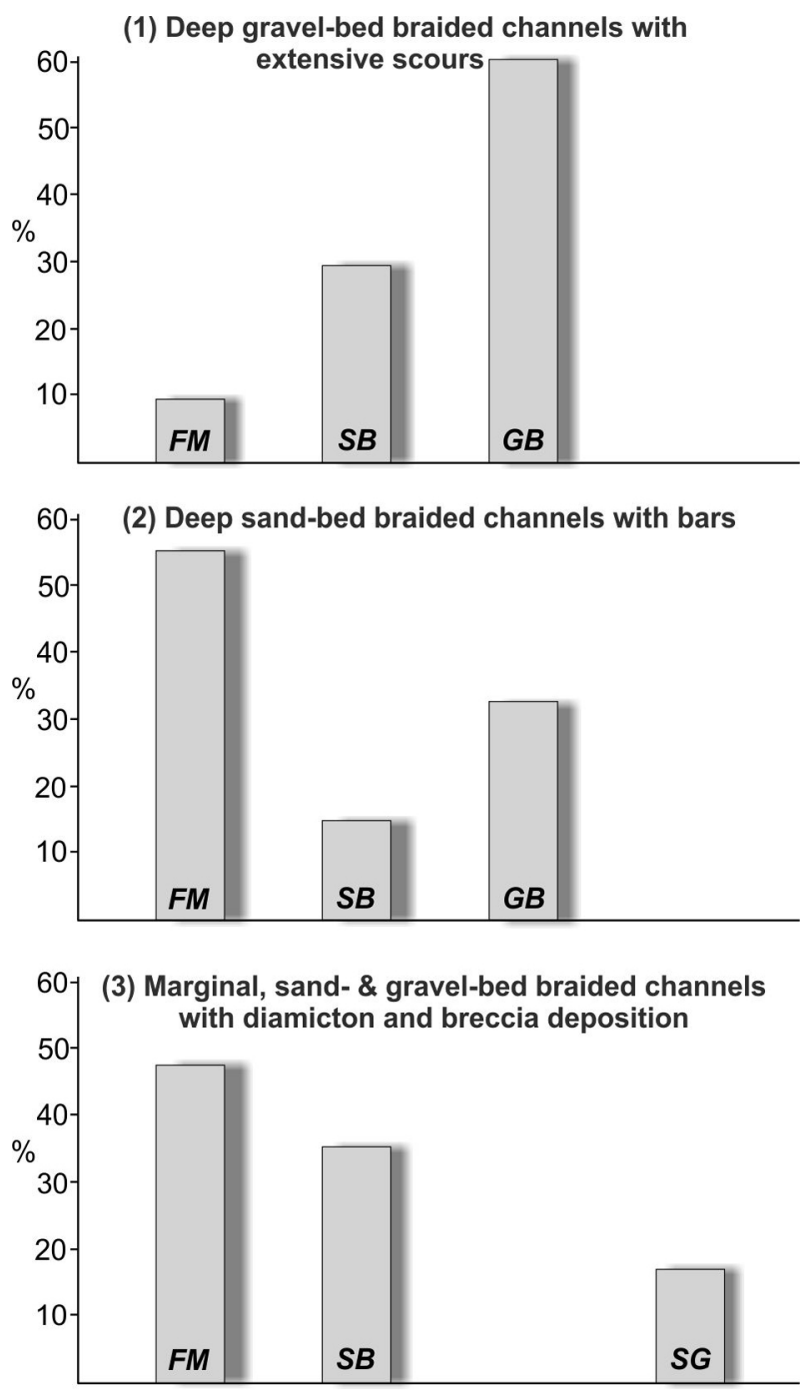

Fig. 6. Architectural elements of three distinguished zones in ice-marginal valley braided river environment. For explanation see Table 1.

are smaller, 0.3-0.4 $\mathrm{m}$ deep and $0.8 \mathrm{~m}$ wide, filled by coarse sand with an admixture of granules. The coarser lithofacies (Gt) often are clast supported, while finer ones contain gravels scattered within coarse sand. Usually reactivation surfaces (one or two) are present within the larger troughs. The trough cross-stratified lithofacies Gt, GSt, SGt, St record 3-D dunes development in conditions of the upper part of lower flow regime, in thalweg zone (Table 5). Some gravel or sandy gravel dunes (Gt, GSt) became replaced by 3-D gravelly sand dunes (SGt) due to a decrease in flow competence (see Łącznica log; Fig. 3). These forms can be classified as 'compound bars' (Harbor, 1998). Some larger troughs represent scour pools - they were dissected in the confluence zones of two channels. They are regarded as indicative of a braided-river fluvial system (Siegenthaler \& Huggenberger, 1993), and were noted on Drawa sandur (e.g. Pisarska-Jamroży \& Zieliński, 2014).

In other channel parts (see Rudnica and Nowe Dwory logs; Fig. 3) sandy high- and low-angle planar cross-stratified lithofacies Sp and Sl occur. The thickness of lithofacies $\mathrm{Sp}$ in the Rudnica succession attains $0.4 \mathrm{~m}$; it comprises coarse and medium sand with an admixture of granules. The laminae of cross-beds are commonly straight, and some reactivation surfaces occur. Lithofacies $\mathrm{Sl}$ in the Nowe Dwory succession consists of medium and coarse sands; the thickness is $0.5 \mathrm{~m}$, and their straight cross laminae dip $10^{\circ}$. Lithofacies Sp can be ascribed genetically to sandy transverse bars developed in the middle part of the lower flow regime (Table 5). Lithofacies Sl were developed due to flattened and washed-out bars with planar cross-stratification which passed into low-angle cross stratification.

Sedimentary successions in all four successions (Rudnica, Brzozowiec, Łącznica and Nowe Dwory) indicate a migration of three-dimensional dunes in a multi-channelled braided river system in IMV (Fig. 7). In this zone prevailed gravelly and sandy bedforms and additionally transverse bars occur (elements GB, SB and FM; Fig. 6). The zone with deep gravel-bed braided channels with extensive scours is characterised by a mean 3-m flow depth, mean flow velocity of $1.9 \mathrm{~ms}^{-1}$, mean stream power of $450.5 \mathrm{Wm}^{-2}$ and mean bed shear stress of $136.8 \mathrm{~Pa}$ (Table 5).

\subsubsection{Deep sand-bed braided channels zone with transverse bars}

Sedimentary successions at three sites, Zwierzyn, Kuźnica Czarnkowska and Walkowice, are dominated by low- and high-angle planar cross-stratified sediments (Sl, Sp, SGp), or in successions there is a balanced participation of planar (Sl, Sp, SGp) and trough cross-stratified sediments (GSt, SGt, St). The low-angle cross-stratified lithofacies $\mathrm{Sl}$ comprises medium and coarse sands; the thickness is $0.7 \mathrm{~m}$ and their straight cross laminae dip 7-10 . Planar cross-stratified lithofacies (Sp and SGp) consist of medium and coarse sand or a mixture of coarse sand with granules, rarely pebbles. The laminae are commonly straight, except for the deformed upper part of laminae of lithofacies $\mathrm{Sp}$ occurring just below trough cross-stratified gravelly sands (SGt) at Zwierzyn (Fig. 4D). There lithofacies occur as cosets (each set $\sim 1 \mathrm{~m}$ thick), while at the other sites they appear as large-scale lithofacies from 1.4 (SGp at Kuźnica Czarnkowska) up to $3 \mathrm{~m}$ (Sp at Walkowice).

Lithofacies Sp, SGp can be ascribed genetically to a sandy or gravelly-sandy transverse bars devel- 


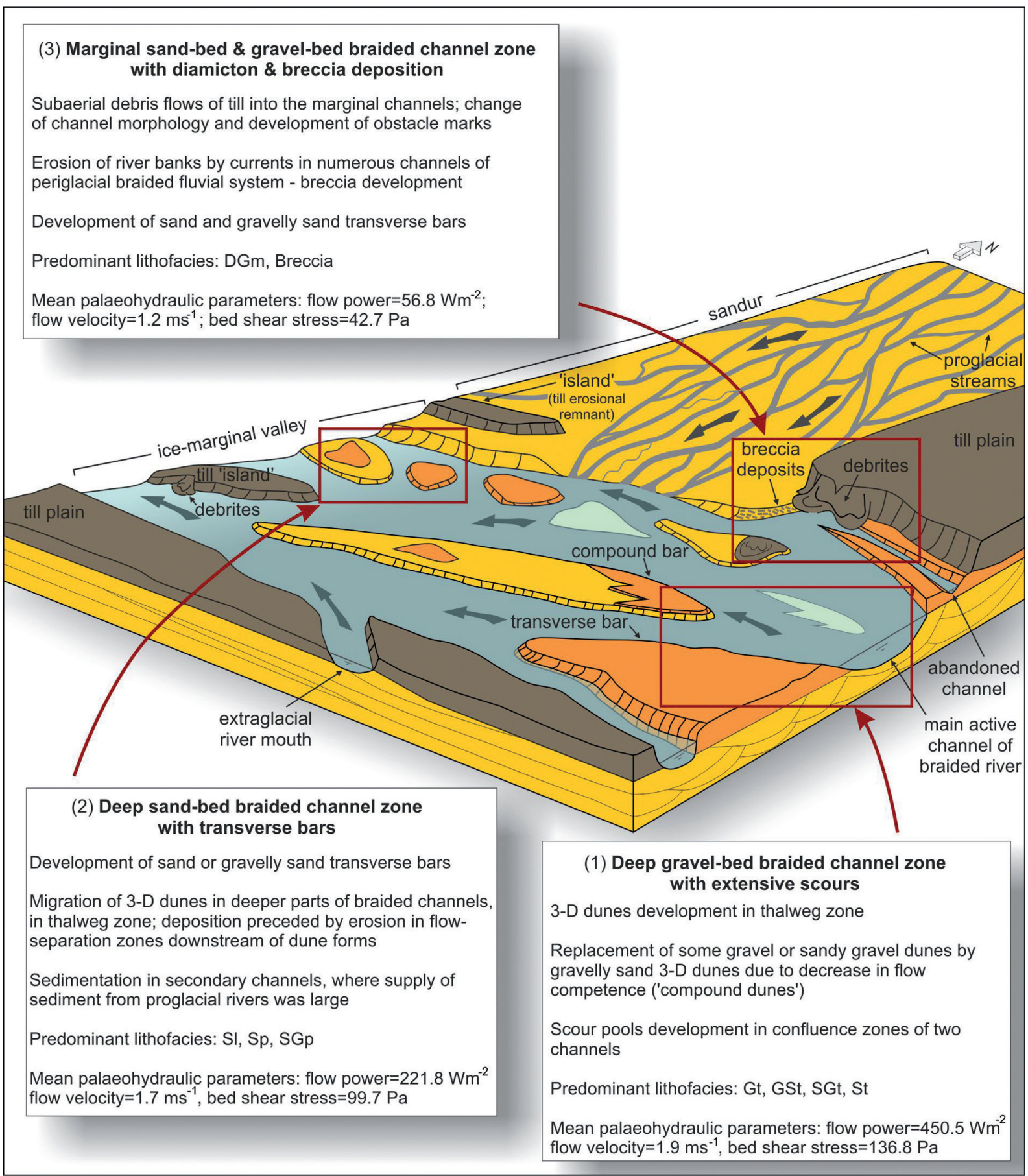

Fig. 7. The Torun-Eberswalde ice-marginal valley during the Pomeranian phase of the Weichselian glaciation with characteristics of three distinguished channel zones in braided river of ice-marginal valley. For explanation see Table 1.

oped in the middle part of the lower flow regime (Table 5; see section 5.2.1). The sedimentary succession at Zwierzyn (Fig. 3) represents conditions of an increasing depth (from 0.8 to even $8.4 \mathrm{~m}$ ) and current velocity (from 0.9 to $2.3 \mathrm{~ms}^{-1}$ ). Largescale planar cross stratification (up to $3 \mathrm{~m}$ thick) at Walkowice and Kuźnica Czarnkowska (Figs 3 and $4 \mathrm{~F})$ reflects large aggradation ratio and large depth caused by confined flow in narrow part of IMV -
Ujście Basin (see Fig. 1). The deformed cross-stratified sands (complex folds) at Zwierzyn (Fig. 4D) evolved metadepositionally in effect of a high sedimentation rate of upper trough cross-stratified gravelly sand (SGt) in a hydroplastic state (see Pisarska-Jamroży \& Weckwerth, 2013).

The gravelly-sand and sandy-gravelly troughshaped sets (SGt, GSt) are between $0.6 \mathrm{~m}$ and $2.8 \mathrm{~m}$ (on average $0.5 \mathrm{~m}$ ) thick and up to $6 \mathrm{~m}$ wide (Fig. 
Table 5. Palaeohydraulic parameters calculated for the braided river in the Torun-Eberswalde ice-marginal valley (in brackets: average values).

\begin{tabular}{|c|c|c|c|c|c|}
\hline \multirow{4}{*}{$\begin{array}{c}\text { Palaeo- } \\
\text { hydraulic } \\
\text { parameters }\end{array}$} & \multicolumn{3}{|c|}{ Braided river zones } & \multicolumn{2}{|c|}{ Bed- and channel forms } \\
\hline & \multirow[t]{3}{*}{$\begin{array}{c}\text { (1) } \\
\text { Deep } \\
\text { gravel-bed } \\
\text { braided } \\
\text { channel } \\
\text { zone with } \\
\text { extensive } \\
\text { scours }\end{array}$} & \multirow[t]{3}{*}{$\begin{array}{c}(2) \\
\text { Deep } \\
\text { sand-bed } \\
\text { braided } \\
\text { channel } \\
\text { zone with } \\
\text { transverse } \\
\text { bars }\end{array}$} & \multirow[t]{3}{*}{$\begin{array}{c}(3) \\
\text { Marginal } \\
\text { deep sand- } \\
\text { \& gravel-bed } \\
\text { braided } \\
\text { channel } \\
\text { zone with } \\
\text { debrite } \\
\text { \& breccia } \\
\text { deposition }\end{array}$} & $\begin{array}{c}\text { Gravelly, } \\
\text { sandy- } \\
\text { gravelly, } \\
\text { gravelly-sandy } \\
\text { \& sandy } \\
\text { trough cross- } \\
\text { stratified } \\
\text { lithofacies } \\
\text { (Gt, GSt, SGt, St) }\end{array}$ & $\begin{array}{c}\text { Sandy \& } \\
\text { gravelly- } \\
\text { sandy } \\
\text { planar } \\
\text { cross- } \\
\text { stratified } \\
\text { lithofacies } \\
\text { (Sp, SGp) }\end{array}$ \\
\hline & & & & Upper part & Middle part \\
\hline & & & & \multicolumn{2}{|c|}{ Lower flow regime } \\
\hline $\begin{array}{l}\text { flow power } \\
{\left[\mathrm{Wm}^{-2}\right]}\end{array}$ & $\begin{array}{c}28.0-3101.0 \\
(450.5)\end{array}$ & $\begin{array}{c}28.0-773.6 \\
(221.8)\end{array}$ & $\begin{array}{c}28.0-96.7 \\
(56.8)\end{array}$ & $\begin{array}{c}28.0-3101.0 \\
(444.3)\end{array}$ & $\begin{array}{c}28.0-161.3 \\
(74.6)\end{array}$ \\
\hline $\begin{array}{l}\text { flow velocity } \\
{\left[\mathrm{ms}^{-1}\right]}\end{array}$ & $\begin{array}{c}1.0-4.7 \\
(1.9)\end{array}$ & $\begin{array}{c}1.0-3.0 \\
(1.7)\end{array}$ & $\begin{array}{c}0.8-1.5 \\
(1.2)\end{array}$ & $\begin{array}{c}1.0-4.7 \\
(2.0)\end{array}$ & $\begin{array}{c}1.0-1.8 \\
(1.3)\end{array}$ \\
\hline $\begin{array}{l}\text { bed shear } \\
\text { stress [Pa] }\end{array}$ & $\begin{array}{c}28.5-657.3 \\
(136.8)\end{array}$ & $\begin{array}{c}28.5-260.5 \\
(99.7)\end{array}$ & $\begin{array}{c}20.4-65.1 \\
(42.7)\end{array}$ & $\begin{array}{c}28.5-657.3 \\
(144.5)\end{array}$ & $\begin{array}{c}28.5-52.1 \\
(42.5)\end{array}$ \\
\hline $\begin{array}{l}\text { flow depth } \\
{[\mathrm{m}]}\end{array}$ & $\begin{array}{c}0.4-6.6 \\
(3.0)\end{array}$ & $\begin{array}{c}1.7-8.4 \\
(3.4)\end{array}$ & $\begin{array}{c}1.2-3.0 \\
(2.1)\end{array}$ & $\begin{array}{c}1.5-8.4 \\
(3.7)\end{array}$ & $\begin{array}{c}0.4-3.1 \\
(2.0)\end{array}$ \\
\hline $\begin{array}{l}\text { Froude } \\
\text { number }\end{array}$ & 0.40 & 0.32 & 0.30 & 0.40 & 0.30 \\
\hline
\end{tabular}

4E). The sandy troughs (St) usually are smaller; 0.4 $\mathrm{m}$ deep and $1.2 \mathrm{~m}$ wide, and are filled by coarse and medium sand with an admixture of granules. Reactivation surfaces (one or two) usually are present within the larger troughs. Trough cross-stratified lithofacies St, SGt and GSt indicate conditions of upper part of lower flow regime (Table 5). In the deeper part of braided channels, in the thalweg zone, sandy, gravelly-sandy and sandy-gravelly 3-D dunes migrated. Deposition was preceded by erosion in flow-separation zone downstream of dune forms. Trough cross-stratified sediments (lithofacies St, SGt and GSt) can be viewed as minor channels that migrated laterally, but in the Zwierzyn succession channels of depths of up to 2.8 $\mathrm{m}$ were noted, which can be interpreted as major channels of a braided river (Fig. 4E).

In the braided river system transport processes were not regular but occurred as a series of pulses and sediments 'slugs', and were dependent of the supply of proglacial sediments from the northern sandurs (Drawa, Gwda in studied IMV part here). Sedimentation of successions in this zone occurred in places where the supply of sediment from proglacial rivers was greater, unlike places where water supply was large to evolve extra-large scale major channels (see Zwierzyn, Figs 3, 4E and 7). In this zone prevailed transverse bars, gravelly and sandy bedforms (elements FM, GB and SB; Fig. 6). The zone with deep sand-bed braided channels with transverse bars is characterised by $3.4 \mathrm{~m}$ of mean flow depth, $1.7 \mathrm{~ms}^{-1}$ of mean flow velocity, 221.8 $\mathrm{Wm}^{-2}$ of mean stream power and 99.7 $\mathrm{Pa}$ of mean bed shear stress (Table 5).

\subsubsection{Marginal sand-bed and gravel-bed braided channels zone with diamicton and breccia deposition}

At two sites (Atanazyn and Rozwarzyn) occur sediments that are unique for IMV environment: diamicton and breccia sediments (Figs 3 and 5). The massive, gravelly diamicton of debris-flow origin at Atanazyn is characterised by a disorganised gravel fabric (Fig. 5A). The matrix-supported framework consists of pebbles and cobbles. The massive, gravelly diamicton represents a subaerial, cohesive debris flow (Pisarska-Jamroży \& Zieliński, 2011; Weckwerth \& Pisarska-Jamroży, in press). The parent material, a glacial till, underwent gravitational transport by solifluction. The unconsolidated sediments derived from the active layer of the permafrost. The debris slid from the till banks (eroding till plain) into the channels and caused changes in channel morphology (Weckwerth \& Pisarska-Jamroży, in press). The deposition of debris flows took place in marginal channels of the IMV 
braided river (Fig. 7). At Rozwarzyn occurs also a sediment of debris-flow origin - debris-flow breccia (Fig. 5E). Debris-flow breccia has a diamictic matrix and silty-clayey clasts with sharp edges, rough and irregular surface, which are disoriented. The matrix of debris-flow breccia is massive or locally cross-stratified (Weckwerth \& Pisarska-Jamroży, in press).

At both sites (Atanazyn and Rozwarzyn) occur fluvial breccia sediments (Fig. 5B-D). At Atanazyn the fluvial breccia consists of diamict clasts and massive sandy matrix. The clasts have a tabular shape resulting from the disintegration of the source rock (till) following joints formed during postdepositional weathering under periglacial conditions. The till clasts show a well-developed imbrication suggestive of deposition in fluvial conditions (Pisarska-Jamroży \& Zieliński, 2011). At Rozwarzyn clasts of fluvial breccia are oriented parallel to the bedding in matrix, imbricated or chaotic (Weckwerth \& Pisarska-Jamroży, in press). Clast surface is smooth and shape varies from sharp edged to rounded. The occurrence of fluvial breccia at Rozwarzyn depended on erosion of till (diamictic) bank of the braided river incised into a till plain (Pisarska-Jamroży \& Zieliński, 2011; Weckwerth \& Pisarska-Jamroży, in press). River banks were extensively eroded laterally by currents in numerous channels of the periglacial braided fluvial system. Fluvial erosion of the river banks initiated gravity flows and dislodged blocks of frozen sediments. Frozen megaclasts derived from mass movements formed obstacle marks on the river bed, changing bed shear stress and causing accumulation of subaqueous disintegrated clasts in shadows behind megaclasts (Weckwerth \& Pisarska-Jamroży, in press). The clasts of breccias with cross-stratified matrix were transported over a larger distance than clasts of fluvial breccias characterised by a massive matrix (Weckwerth \& Pisarska-Jamroży, in press).

Sedimentation of debris-flow diamictons and breccia sediments can occur in sandy, shallow, abandoned channels (Atanazyn site) as well as in deep gravelly channels (Rozwarzyn site). The sedimentary successions at both sites indicate conditions in which aggradation processes in marginal channels of braided river prevailed. In this zone transverse bars, sandy bedforms and gravity flows predominated (elements FM, SB and SG; Fig. 6). The zone with marginal braided channels with debrite and breccia deposition is characterised by $2.1 \mathrm{~m}$ of mean flow depth, $1.2 \mathrm{~ms}^{-1}$ of mean flow velocity, $56.8 \mathrm{Wm}^{-2}$ of mean stream power, $42.7 \mathrm{~Pa}$ of mean bed shear stress, and 0.26 of Froude number (Table 5).

\section{Palaeohydraulic parameters of braided river in Toruń-Eberswalde IMV}

Calculated palaeohydraulic parameters for the Torun-Eberswalde IMV (Table 5) are clearly different from parameters calculated for rivers occurring in non-IMVs fluvial settings in Europe. Braided rivers supplied huge amounts of sediment-laden waters from northern sources; additionally extraglacial rivers such as the pre-Noteć and the pre-Warta provided to the IMV some waters with load. Nevertheless, the northern, proglacial rivers controlled most of the IMV depositional processes during the main phase of IMV development.

Bed shear stress in the deepest troughs in the Torun-Eberswalde IMV reached maximum values 657 $\mathrm{Pa}$, while a minimum of 20.4 Pa occurred in marginal parts of a braided river system in the IMV, where aggradation processes prevailed (Table 5). For comparison, the bed shear stress of normal level of waters in the proximal part of sandurs is lower than $15 \mathrm{~Pa}$, while ablation floods reach 120-400 Pa (Ashworth \& Ferguson, 1986). In Pleistocene deep gravel-bed rivers bed shear stress reaches 25-75 $\mathrm{Pa}$, in shallow gravel-bed rivers - 15-20 $\mathrm{Pa}$, in deep sand-bed rivers - 25-35 $\mathrm{Pa}$, and in shallow sandbed rivers - 10-25 Pa (Zieliński, 1993). Catastrophic floods related to subglacial lake drainage reach 90 Pa (Lord \& Kehew, 1987; Komar, 1989), or between 75 and $250 \mathrm{~Pa}$ (Zieliński, 1993). Bed shear stress calculated for the braided river flowing during the Pomeranian phase in the Torun-Eberswalde IMV main deepest gravel-bed braided channel (zone 1) and can be interpreted as a catastrophic flood (250$657 \mathrm{~Pa}$; see Table 5) or as typical of ablation floods (120-250 Pa). In sand-bed channel zone with bars (zone 2) bed shear stress is typical as of ablation floods. Only in the marginal parts of the braided river system (zone 3) in the Torun-Eberswalde IMV does mean bed shear stress reach only $42 \mathrm{~Pa}$, a value typical of Pleistocene deep gravel-bed rivers (see Zieliński, 1993).

The mean flow depth in the Torun-Eberswalde IMV, estimated on the basis of channel forms and bed form height, reaches $2.8 \mathrm{~m}$ (Table 5), while in main gravelly and sandy channels was $3.2 \mathrm{~m}$ (up to 8.4 ), and in marginal channels $2.1 \mathrm{~m}$. In the eastern part of the Torun-Eberswalde IMV (Torun Basin) the depth of flow reaches 1-3 m (Weckwerth, 2013), and in the Warsaw-Berlin IMV 1.4-1.6 m (Antczak, 1986).

The middle and western part of the Torun-Eberswalde IMV studied was characterised by larger supply of water with sediments in comparison with the easterly Torun Basin, due to direct supply 
of sandur rivers with sediments. e.g. Gwda, Drawa, Wda (Fig. 1). The flow velocity for the middle and western part of Torun-Eberswalde IMV was also higher $(0.8-4.7 \mathrm{~m} / \mathrm{s})$ than values noted in the Torun-Basin (0.3-1.6 ms ${ }^{-1}$; Weckwerth, 2013), and for the Warsaw-Berlin IMV (0.8-2.3 ms ${ }^{-1}$; Antczak, 1986). The flow velocity for the studied part of Torun-Eberswalde IMV was higher in the deepest gravel-bed channels (up to $4.7 \mathrm{~ms}^{-1}$ ), and the lowest in the marginal channels (up to $1.5 \mathrm{~ms}^{-1}$ ).

The flow power in the analysed part of the Torun-Eberswalde IMV varies significantly from 28 $\mathrm{Wm}^{-2}$ for transverse bar deposition up to $3101 \mathrm{Wm}^{-2}$ for the deepest troughs in gravelly sediments (Table 5). Average flow power for contemporary floods of braided rivers is between 150 and $180 \mathrm{Wm}^{-2}$ (Zieliński, 2014). However, flow power for catastrophic floods reaches tens of thousands, even hundreds of thousands of $\mathrm{Wm}^{-2}$ (Baker \& Costa, 1987; Russell, 2005). Comparison of the flow power in the studied part of the Torun-Eberswalde IMV and from the literature (see Boothroyd \& Ashley, 1975; Zieliński, 1993; Blažauskas et al., 2007) indicate that the flow power in IMV was typical (for most of sediments in IMV) as for gravel-bed rivers (30-300 $\left.\mathrm{Wm}^{-2}\right)$, in marginal channels $\left(<70 \mathrm{Wm}^{-2}\right)$ as for sand-bed rivers, and in central, deepest troughs (300-3101 Wm-2) as for catastrophic floods.

The Froude number decreases from sediments deposited in deep gravel-bed braided river, through deep sand-bed braided river to the marginal deep channels of the braided river (Fig. 8). For gravelly and sandy trough cross-stratified sediments deposited in the upper part of lower flow regime (lithofacies Gt, GSt, SGt, St; Table 5) the Froude number reaches 0.4 , while for sandy and

Normalized, mean palaeohydraulic parameters in three zones of IMV braided river

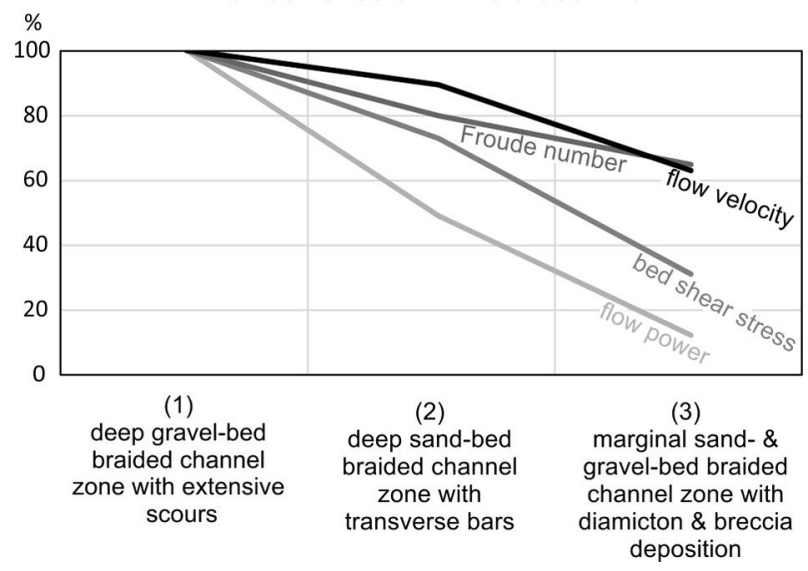

Fig. 8. Trend of normalised, mean values of palaeohydraulic parameters in three zones of braided channels. sandy-gravelly planar cross-stratified lithofacies $(\mathrm{Sp}, \mathrm{SG}$ ) deposited in the middle part of lower low regime it reaches 0.3 .

All calculated parameters show that the braided river in the Torun-Eberswalde is comparable to proglacial floods and catastrophic floods on sandurs. But it is worth noting that the amplitude of flow power, bed shear stress and flow velocity is significant, that is, they changed in a wide range, e.g. from a flow typical of gravel-bed braided river up to a megaflood. All collected water and supplied sediments, mainly from the northern sandurs and additionally from extraglacial inflows, were uncommonly huge in comparison to any other river in non-marginal settings in Europe. It is speculated that the normal water level in the Torun-Eberswalde IMV was similar to the level during proglacial floods occurring on sandurs, and the high water level was equivalent to catastrophic floods (megafloods, outburst floods).

\section{Periglacial factors controlling sedimentation in IMV}

During periglacial conditions in the foreland of the Pomeranian ice sheet a braided river system was functional in the Torun-Eberswalde IMV (Galon, 1961; Kozarski 1965). Deposition of fluvial IMV successions in fluvioperiglacial environments (= periglacial fluvial conditions) was controlled by cyclic fluctuations and variable feeding of fluvial system by rivers with nival and proglacial regimes (Van Huissteden et al., 2001; Vandenberghe, 2002; Zieliński, 2007; Pisarska-Jamroży \& Zieliński, 2011; Weckwerth \& Pisarska-Jamroży, in press). The fluvial system was overprinted by thermoerosion, mass flow processes and short fluvial reworking of glacigenic sediments (Pisarska-Jamroży \& Zielinski, 2011; Weckwerth, 2013; Weckwerth \& Pisarska-Jamroży, in press).

The periglacial climate during the decay of the Pomeranian ice sheet favoured extensive lateral thermoerosion of the braided channels. A significant effect of erosion processes in the braided river system was the formation of fluvial breccias (see Bridge \& Diemer, 2003; Murton et al., 2006; Lewin \& Gibbard, 2010; Murton \& Belshaw 2011; Pisarska-Jamroży \& Zieliński, 2011). Periglacial conditions were also responsible for the subaerial mass movements development which can derive from active layer of permafrost. In effect of debris flow were deposited in the braided river channel debrites: massive gravelly diamicton (DGm lithofacies 
at Atanazyn site) and debris-flow breccia (at Rozwarzyn site).

During the Pomeranian phase (c. 16-17 kyr BP) in the foreland of the Scandinavian ice sheet intensive aeolian processes across Europe (Kasse, 1997; Vanderberghe, 2003; Zieliński et al., in press) are noted. The active period of aeolian processes was sufficiently long for dunes and coversands to form (Stankowski, 1963a, b; Antczak-Górka, 2005; Weckwerth, 2013), but too short for the development of aeolian traces on quartz grains (Table 3). Mycielska-Dowgiałło $(1993,2001)$ stressed that if the period of aeolian processes was relatively short (several hundreds of years), sediments were dominated by quartz grains with abrasion marked only at their edges. This supports also the occurrence of a very small number of ventifactes north of the Pomeranian phase (Krausse, 1996; Antczak-Górka, 2005). Moreover, fluvial sediments in the Torun-Eberswalde IMV contain a very small amount of aeolian grains (2.7\%; Table 3). A similar value was noted by Weckwerth (2013) in the eastern part of the Torun-Eberswalde IMV (Toruń Basin).

\section{Discussion}

On the basis of a wide array of methods, including heavy mineral analysis, textural and structural of sediments, lithofacies and architectural elements of sediments, analysis of rounding and frosting of quartz grains, frequency of sedimentary successions and Markov chain statistical analysis, the main sediment source in the studied part of IMV has been deduced, the main depositional processes have been recognised and zones of braided river system with predominant processes and specific palaeohydrological parameters have been characterised. Moreover, differences between a sandur braided river system and an IMV braided river system were recognised.

The sedimentary record of the Torun-Eberswalde IMV during the Pomeranian phase represents a mixture of material derived from proglacial sediments, eroded sediments from the substratum of IMV, and additionally, extraglacial material coming from southern sources. Near-identical heavy mineral spectra in the Pomeranian sandurs and in the Torun-Eberswalde IMV terrace suggest a mainly northern source of material in the IMV. Small differences in heavy mineral spectra might be ascribed as inherited, previously eroded material from the Pleistocene substratum of IMV or from Miocene/ Pliocene sedimentary outcrops in IMV. A large amount of good rounding and shiny and smooth surfaces of fluvial quartz grains also indicate the erosional origin of the material - from Eemian fluvial sediments (see Weckwerth, 2013) or from Miocene/Pliocene sediments (Galon, 1961). Some minerals may have been supplied by southern, extraglacial rivers, such as e.g. epidote and amphibole (Table 4). Epidote participation is twice higher in the pre-Noteć River terrace, and also slightly higher in the pre-Warta River terrace sediments than in the Torun-Eberswalde IMV terraces. Epidote and amphibole as a commonly occurring mineral in glacigenic sediments can have been supplied from the catchment areas, which mainly consist of glacigenic sediments, of the pre-Noteć and pre-Warta rivers. Not without significance is the alternation of some minerals, e.g. limonite or chlorite. The increasing content of chlorite together with a decreasing content of biotite was probably caused by common secondary transformation. The higher content of limonite in gravels compared to sands is due to the higher porosity of the gravels, so that mineral alteration to limonite was easier in the latter (see Pisarska-Jamroży et al., in press b).

Not without significance for IMV sediment composition were also fluvial sorting processes in IMV and changeability of mineral occurrence, e.g. biotite decreasing downstream because of intensive mechanical abrasion during transport, while amphibole increases slightly downstream as does the transparent/opaque heavy mineral ratio (Pisarska-Jamroży et al., in press b). Interesting relationships between some heavy minerals occur in gravelly and sandy sediments. The high aggradation rate of gravelly lithofacies prevented effective sorting of particles. The heavy mineral fraction was carried in flows transporting gravels - in suspension, but in flows transporting sands - in saltation and as bed load. As a consequence of the mechanical destruction of fragile minerals in the saltation and traction, they are more dominant in finer fractions than in the fraction under study (Pisarska-Jamroży et al., in press b).

Proglacial rivers are typically braided (Maizels, 1995), and many models of braided river sedimentation were developed on the basis of proglacial rivers (e.g. Boothroyd \& Ashley, 1975; Miall, 1977). The sedimentary record of a proglacial subenvironment is controlled among other factors by the discharge magnitude and flow frequency, sediment supply and proglacial topography (Marren, 2005). The meltwater inputs can be low-magnitude-high-frequency, controlled by ablation inputs from the source ice-sheet, or high magnitude-low-frequency, controlled by exceptional inputs (e.g. drainage of subglacial lake). 
Comparing sandurs and IMV sediments, it is difficult to show a unique lithofacies deposited only in an IMV environment. Generally, the commonly occurring structures of IMV sediments are quite similar to structures which are known from middle and distal parts of sandurs (Zieliński, 1993), but the structural scale is larger. The flow in the IMV can be characterised by high-magnitude-low-frequency in comparison with commonly occurring low-magnitude-high-frequency cyclical discharges in Pomeranian sandur rivers. To features of high-magnitude glacial floods, occurring in IMV but not in sandurs here, belong large-scale (>2 m) gravel foresets (see Baker, 1973; Carling, 1996b), large-scale channels (> $2 \mathrm{~m}$ ), and rip-up clasts (blocks of diamict or river bank sediment; see Russell \& Marren, 1999). Planar cross-stratified sediments (up to $3 \mathrm{~m}$ thick) were noted at the Walkowice and Kuźnica Czarnkowska sites, and breccia sediments (equivalent of rip-up clasts sensu Russell \& Marren, 1999; Marren, 2005) - in marginal parts of the IMV braided river system (Atanzyn and Rozwarzyn sites). Although rip-up clasts can occur in non-flood settings, their widespread occurrence has only been documented in jökulhlaup deposits. Additionally, non-flood ripup clasts are typically small $(<1 \mathrm{~m})$, whilst those documented in jökulhlaups are large, from $<0.5$ to $2 \mathrm{~m}$ (Marren, 2005). To the features typically occurring on Pomeranian sandurs and not in the studied part of IMV here, belong: silt and clay layers developed during very low stages (Miall, 1977), thin lithofacies with numerous erosional surfaces and changes in grain size indicating numerous stage changes and frequent channel shifting (Miall, 1977), and rhythmic arrangement of sediment. In the Torun-Eberswalde IMV flowed waters which were equivalents of sandur ablation floods and megafloods. This interpretation is supported by calculated palaeohydraulic parameters. In some sandurs occur also valley incision, which can develop in effect of megafloods reaching IMV. Such valleys incisions were recognised in the western part of the studied IMV-Eberswalde Valley (Pisarska-Jamroży, 2013).

Theoretically, flows in the ice-marginal valley braided river can be caused by two phenomena: (1) very large discharges occurring on a day-today basis, or (2) discharges recorded from the peak summer ablation. The first possibility - short-lived ablation floods - have no direct influence (or are not recorded) on deposition in IMV. Such periodically occurring ablation floods caused sedimentation of rhythmites, which do not occur in the studied part of Torun-Eberswalde IMV successions. In the Torun-Eberswalde IMV flowed a huge quantity of water - collected waters from sandurs, additionally enriched by extraglacial currents, and probably all this together had an influence on the non-cyclic sedimentation style in IMV. The flood frequency probably was much lower than on sandurs. The second possibility - the summer ablation peaks have an influence on flood amplitude in IMV which was probably larger than on sandurs (due to collecting waters from all sandurs). The deposits occurring in IMV can be an equivalent of the largest floods.

The braided rivers on sandurs and in IMV are different as far as channel geometry, main transport and depositional processes are concerned (Table 6). The braided river in the Torun-Eberswalde IMV represents a specific kind of braided river system which can be classified as an 'IMV braided river environment' (Table 6). It is characterised by a confined fluvial system, multipoint supplied by proglacial rivers (sandurs) and extraglacial rivers, lowsloped longitudinal profile, a length of hundreds of kilometres, a quite high aggradation rate but lower than on sandurs, and a lack of vertical sediment cyclicity and occurrence of large-scale channel fills (Fig. 4E, F). Both the 'IMV braided river environment' and 'sandur braided river environment' can be compared with Firth and Slims braided rivers in Canada as described by Miall (2006). The Firth River (equivalent of 'IMV braided river environment') is characterised by the presence of well-described minor and major channels, while the Slims River (equivalent of 'sandur braided river environment ') is characterised by fluvial system, in which channels are more or less equivalent to each other (see also Table 6). In terms of lithofacies characteristics these two braided river environments are difficult to distinguish, yet their fluvial architecture clearly is quite different (see Table 6).

Sedimentary successions occurring in IMV can be assigned to three zones on the basis of predominant depositional processes and palaeohydraulics (Fig. 7): (1) deep gravel-bed braided channel zone with extensive scours, (2) deep sand-bed braided channel zone with transverse bars, and (3) marginal sand-bed and gravel-bed braided channel zone with diamicton and breccia deposition. In the zone with prevailing erosion processes the deepest, probably main, channels of the IMV braided river system (deep gravel-bed braided river - zone 1) developed. Transitional conditions represent the zone in which deep channels and bars (deep sand-bed braided channel with transverse bars -zone 2; Fig. 7; Table 6) evolved. In places where the river banks, made of till (glacial diamicton), were eroded, aggradation processes prevailed (braided river with diamicton and breccia deposition - zone 3 ). 
Table 6. Comparison of sandur braided river environments and ice-marginal valley braided river environments.

\begin{tabular}{|c|c|c|}
\hline Features & Braided river on sandurs & Braided river in ice-marginal valley \\
\hline Fluvial system & Usually unconfined & $\begin{array}{l}\text { Confined by erosional depressions/tunnel } \\
\text { valleys in the bedrock and till plain banks }\end{array}$ \\
\hline Supply & Meltwaters & Sandur rivers, additionally-extraglacial rivers \\
\hline Orientation & from $\sim N$ to $\sim S$ & from $\sim E$ to $\sim W$ \\
\hline $\begin{array}{l}\text { Range of braided } \\
\text { channels orientation }\end{array}$ & $180^{\circ}$ & Negligible \\
\hline Planview shape & $\begin{array}{c}\text { braided } \\
\text { channels } \\
\text { active } \\
\text { areas }\end{array}$ & $\begin{array}{l}\text { inactive } \\
\text { areas } \\
\text { braided } \\
\text { channels }\end{array}$ \\
\hline Longitudinal profile & & \\
\hline Transverse profile & & \\
\hline Length of fluvial system & Dozens of kilometres & Hundreds of kilometres \\
\hline Erosional processes & $\begin{array}{l}\text { Partially erosion of previously } \\
\text { deposited sandur sediments }\end{array}$ & $\begin{array}{l}\text { Extensive erosion of till plain, older sandur } \\
\text { sediments and bedrock }\end{array}$ \\
\hline Aggradation & $\begin{array}{l}\text { Very high, several times higher } \\
\text { than in IMV (thickness } \sim 40 \mathrm{~m} \text { ) }\end{array}$ & $\begin{array}{l}\text { High, several times lower than in sandurs } \\
\text { (thickness up to } 11 \mathrm{~m} \text { ) }\end{array}$ \\
\hline Sediment sorting & Poorly sorted & Moderately and poorly sorted \\
\hline Main fluvial transport & $\begin{array}{l}\text { Hyperconcentrated flow, debris } \\
\text { flow with initial fluvial reworking, } \\
\text { channel flow }\end{array}$ & Channel flow, debris flow in marginal parts \\
\hline $\begin{array}{l}\text { Main depositional forms/ } \\
\text { main sediments }\end{array}$ & $\begin{array}{l}\text { Gravel and sand sheets, debrites, } \\
\text { gravel and sand bedforms }\end{array}$ & $\begin{array}{l}\text { Gravel and sand bedforms, fluvial breccia, } \\
\text { debrites }\end{array}$ \\
\hline Sediment cyclicity & Common & Lacking \\
\hline $\begin{array}{l}\text { Amplitude and frequency } \\
\text { of floods changes }\end{array}$ & Low amplitude, high frequency & High amplitude, low frequency \\
\hline Sheetfloods & Common in proximal part & Rare \\
\hline Incised channels & $\begin{array}{l}\text { Common in distal parts, generally } \\
\text { of smaller scale (up to } 2 \text { m deep) }\end{array}$ & $\begin{array}{l}\text { Very common, generally of larger scale } \\
\text { (up to } 8.5 \mathrm{~m} \text {; average } 2-4 \mathrm{~m} \text { deep) }\end{array}$ \\
\hline
\end{tabular}

Fluvioperiglacial conditions in the Torun-Eberswalde IMV were responsible for the development of breccia sediments and diamicton in marginal parts of the braided river channels. Additionally, some aeolian dunes, coversands and ice-wedge structures were developed (Weckwerth, 2013; Stankowski, 1963a, b), but due to insufficiently long time of aeolian processes generally no traces on quartz grains and no significant frequency of ventifactes were developed. However, in older IMVs, e.g. Głogów-Baruth IMV, occurs a significant amount of aeolian grains (Zieliński et al., in press), which is caused probably by a longer period of aeolian activity than in the Torun-Eberswalde IMV.

On the basis of results presented here, the definition of IMV should be updated. The ice-marginal valley can be ascribed as a broad, glaciation-related valley that formed during deglaciations and periglacial conditions. IMVs can partially utilise older depressions and tunnel valleys. The waters in IMVs flowed more or less parallel to the ice sheet margin and were mainly supplied by proglacial rivers, and additionally by extraglacial rivers, but within the context of water and sediment supply the ex- 
traglacial rivers played only a marginal role during the main phase of IMV development. An important feature for the flow direction in IMVs in Europe is the fact that the Polish-German Lowland (which is part of the Central European Lowland) inclined to the North. In both, sedimentological and geomorphological terms such as ice-marginal valley (= pradolina $=$ Urstromtal $=$ ice-marginal streamway $=$ proglacial spillway = spillway) should be used only for the valley that functioned during the period of main phase development (in case of Torun-Eberswalde IMV - Pomeranian phase of Weichselian glaciation), but in geomorphological significance the term ice-marginal valley can also be used to present-day glaciation-related valleys.

\section{Conclusions}

The following conclusions can be drawn from this study.

- Proglacial streams from the Pomeranian sandurs supplied mainly the Torun-Eberswalde ice-marginal valley. The sediments in ice-marginal valley were additionally supplied by eroded material from the bedrock, e.g. Miocene/Pliocene and Eemian deposits. The supply to ice-marginal valley by extraglacial rivers was most probably marginal, both in water and sediment during the main phase of ice-marginal valley development.

- Three zones can be identified in the Torun-Eberswalde braided river system: firstly - deep gravel-bed braided channel zone, secondly - deep sand-bed braided channel with transverse bars zone, and thirdly - sand-bed and gravel-bed braided river with diamicton and breccia deposits zone. The deep gravel-bed braided channel zone represents the place where migration of three-dimensional dunes occurred and where major channels of braided river system developed. The deep sand-bed braided channel with transverse bars zone are changeable from aggradation processes during which bars were deposited to conditions of sandy deep channel development. Braided river with debrites and breccia deposits zone is characterised by mass movements of semi-frozen sediments from river banks into secondary channels of the braided river, and then fluvial reworking of part of them and formation of breccia sediments.

- The deep gravel-bed braided channel zone with extensive scours (1) represents the place where migration of three-dimensional dunes occurred and where major channels of braided river system developed. The palaeohydraulic parameters show that the flow in this zone was comparable to catastrophic floods (megafloods) and ablation floods.

- The deep sand-bed braided channel zone with transverse bars (2) is characterised by aggradation processes during which bars were deposited and which led to conditions under which sandy deep channels formed. The palaeohydraulic parameters indicate that the flow in this zone was analogous to ablation floods, with events of catastrophic flooding (megafloods).

- The marginal sand-bed and gravel-bed braided channel zone with diamicton and breccia deposition (3) is characterised by mass movements of semi-frozen sediments from channel banks into marginal deep channels of the braided river, and then fluvial reworking of part of them and formation of breccia sediments. On the basis of palaeohydraulic calculations in this zone, flow was comparable to deep gravel-bed braided rivers of glaciated areas.

- Three distinguished zones in ice-marginal valley are well characterised by specific values of palaeohydraulic parameters: stream power, flow velocity and bed shear stress, which values decrease from the zone of deep gravel-bed braided channel with extensive scours (1) to the zone of marginal sand-bed and gravel-bed braided channel zone with diamicton and breccia deposition (3).

- Palaeohydraulic parameters indicate that the middle and western part of the Torun-Eberswalde ice-marginal valley braided river has parameters that are typical of proglacial floods or catastrophic floods; the bed shear stress reached a minimum of $20.4 \mathrm{~Pa}$ in marginal channels and a maximum of $657 \mathrm{~Pa}$ in the deepest main channels; the flow depth varies between 0.4 and 8.4 $\mathrm{m}$; the mean flow velocity reaches $0.8-4.7 \mathrm{~ms}^{-1}$; the flow power ranges from $28 \mathrm{Wm}^{-2}$ (under which transverse bars were deposited), up to $3101 \mathrm{Wm}^{-2}$ during the deepest troughs in gravelly sediment formation. The high amplitude between minimum and maximum parameters values indicate that the flood amplitude in ice-marginal valley was high, but flood frequency was low (as evidenced by a lack of sediment cyclicity).

- Fluvioperiglacial conditions in ice-marginal valley were responsible for the development of mass movements from banks of the ice-marginal valley eroded in a till plain and development of fluvial breccia sediments, indicative of short fluvial transport in fluvio-periglacial conditions. On the other hand, the periglacial conditions in 
the foreland of the Scandinavian ice sheet did not last long enough and left no clear traces on the surface of quartz grains.

- The ice-marginal valley braided river environment was characterised by a confined fluvial system, the occurrence of large-scale major channels, a high aggradation ratio (but lower than on sandurs), the coexistence of sand-bed and gravel-bed braided channels, and a length of hundreds of kilometres.

- The whole spectrum of distinguished sediments can occur on sandurs as well as in ice-marginal valleys, except for fluvial breccia which can be considered as a sediment typical of marginal channels of ice-marginal valley, but not of sandurs.

\section{Future research and relevance for earth sciences}

The present paper outlines the current state of knowledge of the Torun-Eberswalde IMV and the scenario of fluvial deposit development during the Pomeranian phase of the Weichselian glaciation. However, further work is needed here as well as in older valleys on the Polish-German Plain, as a comparative study. Geological studies in ice-marginal valleys can help understand the development of the area, and facilitate the exploitation of unconsolidated sediments. Several problems still remain unresolved, among others, the alternation of narrow valleys (e.g., Ujście Basin) and wide basins (e.g., Gorzów Basin) in the Torun-Eberswalde IMV, and the morphological variability of braided river system bed forms and channel forms over their entire length.

The detailed lithofacies analysis carried out so far in the Torun-Eberswalde IMV have yielded new opportunities for recognition and better description of depositional mechanisms of a braided river system under periglacial fluvial conditions. There still is a need for additional case studies to serve as a basis for a wide variety of interpretative studies. Observations of natural sand-bed and gravel-bed braided channels and flume observations and models have provided a thorough understanding of the formational processes of most bed- and channel forms. Experimental studies are also necessary to account for the preservation of frozen or semi-frozen diamict clasts, sandy clasts and silty clasts in fluvial current environments and in debris flows deposits (see Pisarska-Jamroży \& Zieliński, 2011; Weckwerth \& Pisarska-Jamroży, in press).
An alternation between valley incision and channel aggradation responded to changes in discharge regime and sediment supply associated with climate fluctuations during the Pomeranian phase of the Weichselian glaciation. Not only is such work of importance in our understanding of the glacial history of the earth, but it will also provide models for the interpretation of earlier periods in earth history.

The application of high-resolution seismic reflection techniques and ground-penetrating radar promises to provide much valuable information on the three-dimensional structure of braided fluvial, provided that both techniques will be used, and in combination with excavated sediments. As noted above, the braided rivers in sandurs and in IMV characterised quite different fluvial architectures, but in terms of lithofacies characteristics these two braided river environments are difficult to distinguish. The results obtained from seismic reflection techniques and ground-penetrating radar can improve our architectural information, and architectural details can be used to constrain mathematical flow models in order to provide precise, specific data on fluid transport paths.

In the Torun-Eberswalde IMV and Pomeranian sandurs described here (rapidly aggraded depositional systems; see Pisarska-Jamroży et al., in press b), specific behaviour of heavy minerals (Pisarska-Jamroży et al., in press b) during fluvial transport calls for experimental studies to be widely applied. There is also a need for comparative studies of other rapidly aggraded environments.

Opportunities also exist within the context of neotectonic activity in the Torun-Eberswalde IMV and its vicinity (see Liszkowski, 1992, 1993; Van Loon \& Pisarska-Jamroży, 2014). Cycles of loading and unloading of the earth's crust as a result of growing and diminishing ice-sheet masses during the Pleistocene and development of seismites are known from numerous places, particularly in the northern hemisphere (Mörner, 1990; Muir-Wood, 2000; Kaufmann et al., 2005; Hampel et al., 2009; Brandes et al., 2012; Van Loon \& Pisarska-Jamroży, 2014). All of these areas, ice-covered during the Pleistocene, are currently usually not affected by tectonic activity. Seismites were recognised in the Torun-Eberswalde IMV in sediments of Warthanian age (Van Loon \& Pisarska-Jamroży, 2014), and it may be expected that soft-sediment deformation structures of seismic origin occur also in strata laid down during Weichselian glaciation. 


\section{Acknowledgements}

I thank Tomasz Zieliński, Tom van Loon and Barbara Woronko for discussions and valuable suggestions that improved the quality of the present contribution. Beata Sternal performed the heavy mineral analyses and Barbara Woronko did rounding and frosting analyses. Thanks go to Andreas Börner for logistical support in the field and worthwhile suggestions, and both reviewers (Piotr Weckwerth and anonymous) for constructive suggestions that helped in refining the paper. The work has been financially supported by a grant from the Polish Ministry of Science and Higher Education (research project no. N N307 057540) and by a grant from the National Science Centre Poland (decision no. DEC-2013/09/B/ ST10/00031).

\section{References}

Antczak, B., 1985. Rhythmites on the lower terraces of the Warta River (Poland) and their paleohydrologic implications. Quaestiones Geographicae 1, 31-43.

Antczak, B., 1986. Transformacja układu koryta i zanik bifurkacji Warty w Pradolinie Warszawsko-Berlińskiej i południowej części przełomu poznańskiego podczas późnego vistulianu [Transformation of the channel pattern and the disappearance of Warta bifurcation in Warsaw-Berlin pradolina and the southern part of the Poznan during the late Vistulian]. AMU Press, Geografia 35, 111 pp.

Antczak-Górka, B., 2005. Głazy rzeźbione przez wiatr jako wskaźniki różnowiekowych stref peryglacjalnych ostatniego zlodowacenia w Polsce Zachodniej [Wind-polished stones as indicators of last-glaciation periglacial zones of various ages in western Poland]. AMU Press, Poznań, 209 pp.

Ashley, G.M., 1975. Rhythmic sedimentation in glacial Lake Hitchcock, Massachusetts Connecticut. [In:] A.V. Jopling, B.V. McDonald (Eds): Glaciofluvial and Glaciolacustrine Sedimentation. Society of Economic Paleontologists and Mineralogists Special Paper 23, 304-320.

Ashworth, P. \& Ferguson, R.I., 1986. Interrelationships of channel processes, changes and sediments in a proglacial braided river. Geografiska Annaler 68A, 361-371.

Bagnold, R.A., 1966. An approach to the sediment transport problem from general physics. [In:] C.R., Thorne, R.C., MacArthur \& J.B., Bradley (Eds): The Physics of Sediment Transport by Wind and Water. American Society of Civil Engineers, New York, 231-291.

Baker, V.R., 1973. Paleohydrology and sedimentology of Lake Missoula flooding in eastern Washington. Geological Society of America, Special Paper 144, 73 pp.

Baker, V.R. \& Costa, J.E., 1987. Flood Power. [In:] L. Mayer \& D. Nash (Eds): Catastrophic Flooding, 1-21. Biddles, Guildford.

Bartczak, E., 2006. Objaśnienia do Szczegótowej Mapy Geologicznej w skali 1:50 000. Arkusz Piła [Explanations to the Detailed Geological Map of Poland 1:50 000, sheet Piła]. PGI Press, Warsaw.
Bjørnsson, H., 1998. Hydrological characteristics of the drainage system beneath a surging glacier. Nature 395, 771-774.

Blažauskas, N., Jurgaitis, A. \& Šinkũnas, P., 2007. Patterns of Late Pleistocene proglacial fluvial sedimentation in the SE Lithuanian Plain. Sedimentary Geology 193, 193-201.

Boothroyd, J.C. \& Ashley, G.M., 1975. Processes, bar morphology and sedimentary structures on braided outwash fans, northeastern Gulf of Alaska. [In:] A.V. Jopling \& B.C. McDonald (Eds): Glaciofluvial and Glaciolacustrine Sedimentation. Society of Economic Paleontologists and Mineralogists Special Publication 23, 193-222.

Börner, A., 2007. Das Eberswalder Urstromtal - Untersuchung zur pleistozänen Landschaftsgenese zwischen Niederem Oderbruch und Werbellinseerinne (Nordost-Brandenburg) [The Eberswalde ice-marginal valley - investigation of the Pleistocene genesis of the landscape between Nieder Oderbruch and the tunnel valley of the Werbellinesee (Northeast Brandenburg)]. Schriftenreihe für Geowissenschaften 17, 118 pp.

Brandes, Ch., Winsemann, J., Roskosch, J., Meinsen, J., Tanner, D.C., Frechen, M., Steffen, H. \& Wu, P., 2012. Activity along the Osning Thrust in Central Europe during the Lateglacial: ice-sheet and lithosphere interactions. Quaternary Science Reviews 38, 49-62.

Bridge, J.S., 2003. Rivers and Floodplains - Forms, Processes and Sedimentary Record. Blackwell, Bodmin, 491 pp.

Bridge, J.S. \& Diemer, J.A., 2003. Quantitative interpretation of an evolving ancient river system. Sedimentology 30, 599-623.

Brodzikowski, K. \& Van Loon, A.J., 1980. Sedimentary deformations in Saalian glaciolimnic deposits near Włostów (Żary area, western Poland). Geologie en Mijnbouw 59, 251-272.

Brodzikowski, K. \& Van Loon, A.J., 1991. Glacigenic sediments. Developments in Sedimentology 49, Elsevier, Amsterdam, 674 pp.

Cant, D.J. \& Walker, R.G., 1976. Development of a braided-fluvial facies model for the Devonian Battery Point Sandstone, Quebec. Canadian Journal of Earth Sciences 13, 102-119.

Carling, P.A., 1996. Morphology, sedimentology and palaeohydraulic significance of large gravel dunes: Altai Mountains, Siberia. Sedimentology 43, 647-664.

Church, M. \& Gilbert, R., 1975. Proglacial fluvial and lacustrine sediments. [In:] A.V. Jopling \& B. McDonald (Eds): Glaciofluvial and glaciolacustrine sedimentation. Society of Economic Paleontologists and Mineralogists Special Publication 23, 22-100.

Costard, F., Dupeyrat, L., Gautier, E. \& Carey-Gailhardis, E., 2003. Fluvial thermal erosion investigations along a rapidly eroding river banks: application to the Lena river (central Siberia). Earth Surface Processes and Landforms 28, 1349-1359.

Fraser, J.Z., 1982. Derivation of a summary facies sequence based on Markov chain analysis of the Caledon outwash: a Pleistocene braided glacial fluvial deposit. [In:] R. Davidson-Arnott (Ed.): Research in 
Glacial, Glacio-fluvial, and Glacio-lacustrine Systems, Geo Books, Norwich, 175-202.

Friend, P.P. \& Moody-Stuart, M., 1972. Sedimentation in the Wood Bay Formation (Devonian) of Spitsbergen: Regional analysis of a late erogenic basin. Norsk Polarinstitutt Skrifter 157, 1-77.

Gadomska, S., 1957. Utwory trzeciorzędowe i czwartorzedowe doliny Noteci w okolicy Krostkowa i Osieka n/Notecią koło Wyrzyska [Tertiary and quaternary sediments of Noteć Valley in the vicinity of Krostków and Osiek near Wyrzysk]. Biuletyn Instytutu Geologicznego 118, 371-393.

Galon, R., 1961. Morphology of the Noteć-Warta (or Torun-Eberswalde) ice marginal streamway. Prace Geograficzne 29, 7-115. [In Polish; English summary].

Galon, R., 1968. New facts and problems pertaining to the origin of the Noteć-Warta Pradolina and the valleys linked with it. Przeglad Geograficzny 40, 307-315.

Gilbert, R., 1975. Sedimentation in Lillooet Lake, British Columbia. Canadian Journal of Earth Sciences 12, 16971711.

Goudie, A.S., 2004. Encyclopedia of Geomorphology. Vol. 1. International Association of Geomorphologists. Taylor and Francis, $1156 \mathrm{pp}$.

Hampel, A., Hetzel, R., Maniatis, G. \& Karow, T., 2009. Three-dimensional numerical modeling of slip rate variations on normal and thrust fault arrays during ice cap growth and melting. Journal of Geophysical Research 114, 8406-8420.

Harbor, D.J., 1998. Dynamics of bedforms in the Lower Mississippi River. Journal of Sedimentary Research 68, 750-762.

Hasholt, B., 1995. Varves in a proglacial Lake, Semilik, South East Greenland. Danish Journal of Geography 95, 92-96.

Jahn, A., 1975. Problems of the Periglacial Zone. PWN Press. Warsaw, 223 pp.

Jaroszewski, W., Marks, L. \& Radomski, A., 1985. Słownik geologii dynamicznej [Dictionary of dynamic geology]. Geological Press, Warsaw, 310 pp.

Kasse, C., 1997. Cold-climate aeolian sand-sheet formation in North-Western Europe (c. 14-12.4 ka); a response to permafrost degradation and increased aridity. Permafrost and Periglacial Processes 8, 295-311.

Karczewski, A.,1968. Wpływ recesji lobu Odry na powstanie i rozwój sieci dolinnej Pojezierza Myśliborskiego i Niziny Szczecińskiej [Influence of Odra Lobe recession on the Myślibórz Lakeland and Szczecin Lowland valleys development]. Prace Komisji Geograficzno-Geologicznej PTPN 8, 108 pp.

Kaufmann, G., Wu, P. \& Ivins, E.R., 2005. Lateral viscosity variations beneath Antarctica and their implications on regional rebound motions and seismotectonics. Journal of Geodynamics 39, 165-181.

Kehew, A.E., Lord, M.L., Kozlowski, A. \& Fisher, T.G., 2009. Proglacial megaflooding along the margins of the Laurentide Ice Sheet. [In:] D.M. Burr, P.A. Caring \& V.R. Baker (Eds): Megaflooding on Earth and Mars, 104-127. Cambridge University Press, Cambridge.

Klimek, K., 1972. Wspótczesne procesy fluwialne i rzeźba równiny Skeidararsandur (Islandia) [Fluvial processes and morphology of the Skeidararsandur (Iceland)]. Prace Geograficzne IGiPZ PAN, 94 pp.

Komar, P.D., 1989. Physical processes of waves and currents and the formation of marine placers. CRC Critical Reviews in Aquatic Sciences 1, 393-423.

Komar, P.D., 2007. The entrainment, transport and sorting of heavy minerals by waves and currents. [In:] M.A. Mange \& D.T. Wright (Eds): Heavy Minerals in Use. Developments in Sedimentology 58, 3-48. Elsevier, Amsterdam.

Kondracki, J., 2000. Geografia regionalna Polski [Regional geography of Poland]. PWN Press, Warsaw, 441 pp.

Kozarski, S., 1959. O genezie O genezie chodzieskiej moreny czołowej [On the origin of the Chodzież end moraine]. Badania Fizjograficzne nad Polska Zachodnia 5, 45-72. [In Polish; English summary].

Kozarski, S., 1962. Recesja ostatniego lądolodu z północnej części Wysoczyzny Gnieźnieńskiej a kształtowanie się Pradoliny Noteci-Warty [Problem of the recession of the last ice-sheet from the northern part of the Gniezno Plateau and Noteć-Warta ice-marginal valley development]. Prace Komisji Geograficzno-Geologicznej 2, Poznań, 145 pp.

Kozarski, S., 1965. Zagadnienie drogi odpływu wód pradolinnych z zachodniej części Pradoliny Noteci-Warty [The problem of the outflow from the western part of Noteć-Warta Pradolina]. Prace Komisji Geograficzno-Geologicznej 5, 1-87.

Kozarski, S., 1966. Die glazialen Abflußverhältnisse im westlischen Teil des Noteć-Warta Urstromtales. Wissenschaftliche Zeitschrift der Ernst-Moritz-Arndt-Universität Greifswald 15, 63-72.

Kozarski, S., 1986. Skale czasu a rytm zdarzeń zdarzeń geomorfologicznych vistulianu na Niżu Polskim [Time scales and rhythm of geomorphological events during Vistulian in the Polish Lowlands]. Czasopismo Geograficzne 57, 247-270.

Krausse, K., 1996. Windkanter - interessante Geschiebe Norddeutschlands. Geschiebekunde Aktuell 12, 105-110.

Krüger, J., 1997. Development of minor outwash fans at Kötulujökull, Iceland. Quaternary Science Reviews 16, 649-659.

Lewin, J. \& Gibbard, P.L., 2010. Quaternary river terraces in England: forms, sediments and processes. Geomorphology 120, 293-311.

Liedtke, H., 1961. Die Talentwicklung im Oderbruch und im unteren Odertal. Die Zeitschrift der Gesellschaft für Erdkunde zu Berlin 92, 259-280.

Lindé, K. \& Mycielska-Dowgiałło, E., 1980. Some experimentally produced microtextures on grain surfaces of quartz sand. Geografiska Annaler 62A, 171-184.

Lindner, L., 1992. Czwartorzęd - osady, metody badań, stratygrafia [The Quaternary - deposits, research methods, stratigraphy]. PAE Press, Warsaw, 683 pp.

Liszkowski, J., 1992. Wpływ plejstoceńskich ladolodów na stan, strukture, kinematyke i dynamike ziemi [Impact of the Pleistocene ice sheets structure, kinematics and dynamics of the earth]. [In:] Materiały VII Sympozjum Glacitektonicznego [Proceedings of Glacitectonics Symposium], Zielona Góra, 217-253. 
Liszkowski, J., 1993. The effects of Pleistocene ice-sheet loading-deloading cycles on the bedrocks structure of Poland. Folia Quaternaria 64, 7-23.

Lord, M.L. \& Kehew, A.E., 1987. Sedimentology and paleohydrology of glacial-lake outburst deposits in southeastern Saskatchewan and nothwestern North Dakota. Geological Society of America Bulletin 99, 663673.

Louis, H., 1936. Neuere Forschungen über die Urstromtäler besonders im mittleren Norddeutschland. Comptes Rendus du Congrès international de Géographie, Warsaw 1934, 335-341.

Lowright, R., Williams, E.G. \& Dachille, F., 1972. An analysis of factors controlling deviations in hydraulic equivalence in some modern sands. Journal of Sedimentary Petrology 42, 635-645.

Lüthgens, C., Böse, M. \& Preusser, F., 2011. Age of the Pomeranian ice-marginal position in northeastern Germany determined by Optically Stimulated Luminescence (OSL) dating of glaciofluvial sediments. Boreas 40, 598-615.

Maas, G., 1904. Zur Entwicklungsgeschichte des sog. Thorn-Eberswalde Haupttales. Zeitschrift der Deutschen Geologischen Gesellschaft 56, 40-49.

Mange, M.A. \& Maurer, H.F.W., 1992. Heavy minerals in colour. Chapman and Hall, London, $147 \mathrm{pp}$.

Maizels, J., 1993. Lithofacies variations within sandur deposits: the role of runoff regime, flow dynamics and sediment supply characteristic. Sedimentary Geology 85, 299-325.

Maizels, J.K., 1995. Sediments and landforms of modern proglacial terrestrial environments. [In:] Menzies, J. (Ed.), Modern Glacial Environments. Butterworth-Heinemann, Oxford, pp. 365- 416.

Marcinkowski, B., 2007. Wykorzystanie składu mineralnego i morfologii ziaren minerałów ciężkich do określania środowiska sedymentacyjnego [Application of the mineral composition and the morphology of mineral grains to the interpretation of the sedimentary environment]. Przeglad Geologiczny 55, 207.

Marks, L., 2012. Timing of the Late Vistulian (Weichselian) glacial phases in Poland. Quaternary Science Reviews 44, 81-88.

Marren, P.M., 2005. Magnitude and frequency in proglacial rivers: a geomorphological and sedimentological perspective. Earth-Science Reviews 70, 203-251.

Marren, P.M., Russell, A.J. \& Knudsen, O., 2002. Discharge magnitude and frequency as a control on proglacial fluvial sedimentary systems. [In:] F.J. Dyer, M.C. Thoms \& J.M. Olley (Eds): The Structure, Function and Management Implications of Fluvial Sedimentary Systems, 297-303. IAHS Publication 276.

Miall, A.D., 1977. A review of the braided-river depositional environment. Earth-Science Reviews 13, 1-62.

Miall, A.D., 1978. Lithofacies types and vertical profile models in braided river deposits: a summary. [In:] A.D. Miall (Ed.): Fluvial Sedimentology. Canadian Society of Petroleum Geologists 5, 597-604.

Miall, A.D., 2006. The Geology of Fluvial Deposits: Sedimentary Facies, Basin Analysis and Petroleum Geology. Springer, $582 \mathrm{pp}$.
Migoń, P., 2006. Geomorfologia [Geomorphology]. PWN Press. Warsaw, 464 pp.

Mizerski, W. \& Sylwestrzak, H., 2002. Stownik geologiczny [Geological dictionary]. PWN Press, Warsaw, 80 pp.

Mörner, N.A., 1990. Glacioisostatic and long term crustal movements in Fennoscandia with respect to lithospheric and atmospheric processes and properties. Tectonophysics 176, 13-24.

Muir-Wood, R., 2000. Deglaciation seismotectonics: a principal influence on intraplate seismogenesis at high latitudes? Quaternary Science Reviews 19, 1399 1411.

Murton, J.B., 1996. Near-surface brecciation of chalk, Isle of Thanet, South-East England: a comparison with ice-rich brecciated bedrocks in Canada and Spitsbergen. Permafrost and Periglacial Processes 7, 153-164.

Murton, J.B. \& Belshaw, R.K., 2011. A conceptual model of valley incision, planation and terrace formation during cold and arid permafrost conditions of Pleistocene southern England. Quaternary Research 75, 385-394.

Mycielska-Dowgiałło, E., 1993. Estimates of Late Glacial and Holocene aeolian activity in Belgium, Poland and Sweden. Boreas 22, 165-170.

Mycielska-Dowgiałło, E., 2001. Wpływ warunków klimatycznych na cechy strukturalne i tekstualne osadów mineralnych [The influence of climatic conditions on structural and textual features of deposits]. [In:] A. Karczewski \& Z. Zwoliński (Eds): Funkcjonowanie geosystemów w zróżnicowanych warunkach morfoklimatycznych - monitoring, ochrona, edukacja [The functioning of geosystems under different morphoclimatic conditions - monitoring, protection, education]. Poznań, 377-394.

Mycielska-Dowgiałło, E. \& Woronko, B., 1998. Analiza obtoczenia i zmatowienia powierzchni ziarn kwarcowych frakcji piaszczystej i jej wartość interpretacyjna [Rounding and frosting analysis of quartz sandgrain surfaces and their interpretative significance]. Przeglad Geologiczny 46, 1275-1281.

Niewiarowski W., 1969. The relation of the Drwęca valley to the Noteć-Warta (Torun-Eberswalde) Pradolina and its role in the glacial and lateglacial drainage system. Geographica Polonica 17, 173-188.

Niewiarowski, W., 1983. Postglacjalne ruch pionowe skorupy ziemskiej na Pojezierzu Krajeńskim w świetle badań geomorfologicznych. Przeglad Geograficzny 55, 13-31.

Ost, H.G., 1932. Morphologischen Studien im Drage- und Küddowgebiet. Abhandlung und Berichte der Naturwissenschaftlichen Abteilung der Grenzmarkischen Gesellschaft zur Erforschung und Pflege 7, 3-68.

Ost, H.G., 1935. Neuere Anschauungen zur Entwicklungsgeschichte eines norddeutschen Urstromtales. Zeitschrift für Gletscherkunde 22, 96-108.

Passchier, S., 2007. The Use of Heavy Minerals in the Reconstruction of Ice-Sheet Drainage Patterns: An Example from the Edge of the East Antarctic Ice Sheet. [In:] M.A. Mange \& D.T. Wright (Eds): Heavy minerals in use. Developments in Sedimentology 58, 677-700. Elsevier, Amsterdam. 
Paterson, W.S.B., 1994. Hydraulics of glaciers. Glaciers sliding. Deformation of subglacial till. Structures and fabric in glaciers and ice sheet. [In:] W.S.B. Paterson (Ed.): The Physics of Glaciers, 103-203. Pergamon Press, Oxford.

Pisarska-Jamroży, M., 2006. Transitional deposits between endmoraine and sandur plain in the Pomeranian glaciomarginal zone of NW Poland: a missing component of ice-contact sedimentary models. Boreas $35,126-141$.

Pisarska-Jamroży, M., 2007. Glacifluwialne facje strumieni przeciążonych zawiesiną na przykładzie plejstoceńskich osadów wschodniej Jutlandii i Pomorza Zachodniego [Glaciofluvial facies of hyperconcentrated flow (Pleistocene of Denmark and Western Pomerania)]. Przeglad Geologiczny 55, 503-510.

Pisarska-Jamroży, M., 2008a. Zonation of glaciomarginal environment inferred from Pleistocene deposits of Myślibórz Lakeland, NW Poland. Geografiska Annaler 90A, 237-249.

Pisarska-Jamroży, M., 2008b. Mechanizmy depozycji w strefie glacimarginalnej zlodowacenia Wisty. Studium sedymentologiczne z Pomorza Zachodniego i Jutlandii [Depositional mechanisms in glaciomarginal zone of the Vistulian glaciation. Sedimentological study of Western Pomerania and Jutland]. Kazimierz Wielki University Press, Bydgoszcz, 163 pp.

Pisarska-Jamroży, M., 2013. Varves and megavarves of the Eberswalde Valley (NE Germany) - a key for the interpretation of glaciolimnic processes. Sedimentary Geology 291, 84-96.

Pisarska-Jamroży, M. \& Weckwerth, P., 2013. Soft-sediment deformation structures in a Pleistocene glaciolacustrine delta and their implications for the recognition of subenvironments in delta deposits. Sedimentology 60, 637-665.

Pisarska-Jamroży, M. \& Zieliński, T., 2011. Genesis of a till/sand breccia (Pleistocene, Noteć Valley near Atanazyn, central Poland). Sedimentary Geology 236, 109-116.

Pisarska-Jamroży, M. \& Zieliński, T., 2012. Specific erosional and depositional processes in a Pleistocene subglacial tunnel in the Wielkopolska region, Poland. Geografiska Annaler 94A, 429-443.

Pisarska-Jamroży, M. \& Zieliński, T., 2014. Pleistocene sandur rhythms, cycles and megacycles: Interpretation of depositional scenarios and palaeoenvironmental conditions. Boreas 43, 330-348.

Pisarska-Jamroży, M., Van Loon, A.J., Woronko, B. \& Sternal, B., in press a. Heavy-mineral analysis as a tool to trace the source areas of sediments in an ice-marginal valley, with an example from the Pleistocene in northwest Poland. Netherlands Journal of Geosciences. doi: 10.1017/njg.2014.37

Pisarska-Jamroży, M., Van Loon, A.J. \& Woronko, B., in press $b$. Sorting of heavy minerals in sediments deposited at a high accumulation rate, with examples from sandurs and an ice-marginal valley in NW Poland. GFF. doi: http:/ /dx.doi.org/10.1080/11035897. 2015.1009158.
Plink-Björklund, P. \& Ronnert, L., 1999. Depositional processes and internal architecture of Late Weichselian ice-margin submarine fan and delta settings, Swedish west coast. Sedimentology 46, 215-234.

Racinowski, R. \& Rzechowski, J., 1969. Minerały ciężkie w glinach zwałowych Polski środkowej [Heavy minerals in the tills of middle Poland]. Geological Quarterly 13, 479-490.

Randriamazaoro, R., Dupeyrat, L., Costard, F. \& Gailhardis, E.C., 2007. Fluvial thermal erosion: heat balance integral method. Earth Surface Processes and Landforms $32,1828-1840$.

Russell, A.J., 2005. Catastrophic floods. [In:] C.S. Richard, L.R.M. Cocks \& I.R. Plimer (Eds): Encyclopedia of Geology, Elsevier, Amsterdam, 628-641.

Russell, A.J. \& Marren, P.M., 1999. Proglacial fluvial sedimentary sequences in Greenland and Iceland: a case study from active proglacial environments subject to jökulhlaups. Skeiðararsandur, Iceland. Global and Planetary Change 28, 203-226.

Saunderson, H.C. \& Jopling, A.V., 1980. Palaeohydraulics of a tabular cross-stratified sand in the Brampton esker, Ontario. Sedimentary Geology 25, 169-188.

Schlaak, N., 1993. Studie zur Landschaftsgenese im Raum Nordbarnim und Eberswalder Urstromtal. Berliner Geographische Arbeiten 76, 119 pp.

Siegenthaler, Ch. \& Huggenberger, P., 1993. Pleistocene Rhine gravel: deposits of a braided river system with dominant pool preservation. [In:] J.L. Best \& C.S. Bristow (Eds): Braided Rivers. Geological Society Special Publication 75, 147-162.

Snorrason, Á., Jónsson, P., Sigurdsson, O., Pálsson, S., Árnason, S., Víikingsson, S. \& Kaldal, I., 2002. November 1996 jökulhlaup on Skeiðararsandur outwash plain, Iceland. International Association of Sedimentologists, Special Publication 32, 55-65.

Soons, J.M.,1964. Ice-marginal Drainage Channels in the Rakaia Valley. New Zealander Geographer 20, 153-164.

Stankowski, W., 1963a. Deflation relief of the western part of the Warta-Noteć Interfluve. INQUA, Report of the $6^{\text {th }}$ International Congress on Quaternary, Warsaw, 337-339.

Stankowski, W., 1963b. Rzeźba eoliczna Polski Północno-Zachodniej na podstawie wybranych obszarów [Aeolian relief of NW Poland on the base of selected sites]. Prace Komisji Geograficzno-Geologicznej 4, 147 pp.

Steidtmann, J.R., 1982. Size-density sorting of sand-size spheres during deposition from bedload transport and implications concerning hydraulic equivalence. Sedimentology 29, 877-883.

Szupryczyński, J., 1958. Rzeźba i budowa geologiczna Dębowej Góry. Studia Societatis Scientiarium Torunensis 3, 1-13.

Tomczak, A., 1987. Evolution of the Vistula valley in the Torun Basin in the Late Glacial and Holocene. [In:] L. Starkel (Ed.): Evolution of the Vistula river valley during the last 15000 years, 207-232. Geographical Studies, Special Issue 4, Toruń.

Toucanne, S., Zaragosi, S., Bourillet, J.F., Cremer, M., Eynaud, F., Turon, J.L., Fontanier, C, Van Vliet Lanoë, B. \& Gibbard, P.L., 2009a. Timing of massive 'Fleuve 
Manche' discharges over the last 350 kyr: insights into the European Ice Sheet oscillations and the European drainage network from MIS 10 to 2. Quaternary Science Reviews 28, 1238-1256.

Toucanne, S., Zaragosi, S., Bourillet, J.F., Gibbard, P.L., Eynaud, F., Giraudeau, J., Turon, J.L., Cremer, M., Cortijo, E., Martinez, P. \& Rossignol, L., 2009b. A 1.2 My record of glaciation and fluvial discharges from the West European Atlantic margin. Quaternary Science Reviews 28, 2974-2981.

Toucanne, S., Zaragosi, S., Bourillet, J.F., Marieu, V., Cremer, M., Kageyama, M., Van Vliet Lanoë, B., Eynaud, F., Turon, J.L. \& Gibbard, P.L., 2010. The first estimation of Fleuve Manche palaeoriver discharge during the last deglaciation: evidence for Fennoscandian ice sheet meltwater flow in the English Channel ca 20-18 ka ago. Earth and Planetary Science Letters 290, 459-473.

Udden, J.A., 1914. Mechanical composition of clastic sediments. Geological Society of America Bulletin 25, 655744.

Van Andel, T.J., 1950. Provenance, Transport and Deposition of Rhine Sediments. Ph.D. thesis, Groningen University, Groningen. 129 pp.

Vandenberghe, J., 2002. The relation between climate and river processes, landforms and deposits during the Quaternary. Quaternary International 91, 17-23.

Vandenberghe, J., 2003. Climate forcing of fluvial system development: an evolution of ideas. Quaternary Science Reviews 22, 2053-2060.

Van Huissteden, J.C., Gibbard, P.L. \& Briant, R.M., 2001. Periglacial fluvial systems in northwest Europe during marine isotope stages 4 and 3. Quaternary International 79, 75-88.

Van Loon, A.J., 1973. "Habitus" of some heavy minerals from the Tertiary of Southern Limburg (The Netherlands). Mededelingen Rijks Geologische Dienst, Nieuwe serie 23, 39-67.

Van Loon, A.J., 2009. Reflections on subglacial megafloods: their possible cause, occurrence, and consequence for the global climate. Geologos 15, 115-128.

Van Loon, A.J., 2013. The revival of heavy mineral analysis as a tool for sedimentological research. Geologos $19,1-4$

Van Loon, A.J. \& Pisarska-Jamroży, M., 2014. Sedimentological evidence of Pleistocene earthquakes in NW Poland induced by glacioisostatic rebound. Sedimentary Geology 300, 1-10.

Warburton, J., 1999. Environmental change and sediment yield from glacierised basins: the role of fluvial processes and sediment storage. [In:] A.G. Brown \& T.A. Quine (Eds): Fluvial Processes and Environmental Change, 363-384. Wiley, Chichester.

Weckwerth, P., 2013. Ewolucja fluwialnych systemów depozycyjnych $i$ jej uwarunkowania paleośrodowiskowe w Kotlinie Toruńskiej podczas zlodowacenia wisty [The evolution offluvial depositional systems and its palaeoenvironmental controls during the Weichselian glaciation]. Nicolaus Copernicus University Press, Torun, 205 pp. [In Polish; English summary].
Weckwerth, P. \& Chabowski, M., 2013. Heavy minerals as a tool to reconstruct river activity during the Weichselian glaciation (Torun Basin, Poland). Geologos 19, 25-46.

Weckwerth, P. \& Pisarska-Jamroży, M., 2011. Warunki depozycji "brekcji fluwialnej" we wschodniej czesści pradoliny Noteci-Warty [Depositional conditions of the 'fluvial breccia' in the eastern part of the Noteć-Warta ice-marginal valley]. [In:] IX Zjazd Geomorfologów Polskich [9 $9^{\text {th }}$ Convention of Polish Geomorphologists], Poznan, Poland, 164-165. [In Polish]

Weckwerth, P. \& Pisarska-Jamroży, M., in press. Periglacial and fluvial factors controlling the sedimentation of Pleistocene breccia in NW Poland. Geografiska Annaler doi:10.1111/geoa.12082.

Wentworth, C.K.A., 1922. A scale of grade and class terms for clastic sediments. Journal of Geology 30, 377-392.

Widera, M., 2007. Litostratygrafia i paleotektonika kenozoiku podplejstoceńskiego Wielkopolski [Lithostratigraphy and palaeotectonics of the sub-Pleistocene Cenozoic of Wielkopolska]. Seria Geologia 18, UAM Press, Poznań, 224 pp.

Williams, G.P., 1983. Paleohydrological methods and same examples from Swedish fluvial environments. I cobble and boulder deposits, Geografiska Annaler 65A, 227-243.

Wiśniewski, E., 1971. Struktura i tekstura sandru ostródzkiego oraz teras doliny górnej Drwęcy. Prace Geograficzne Instytutu Geograficznego PAN 83, 1-95.

Wiśniewski, E., 1990. Evolution of the Vistula Valley. Geographical Studies 5, 146-153

Wiśniewski, E., 1992. Evolution of the lower Vistula River Valley in the upper Plenivistulian. Quaestiones Geographicae 3, 187-195.

Woldstedt, P., 1935. Über die Geschichte des Küstriner Beckens und der Eberswalder Pforte. Jahrbuch der Königlichen Preussischen Geologischen Landesanstalt 56, 274-291.

Woldstedt, P., 1950. Norddeutschland und angrenzende Gebiete im Eiszeitalter. Koehler Verlag, Stuttgart, 464 p.

Woronko, B., Rychel, J., Karasiewicz, M.K., Ber, A., Krzywicki, T., Marks, L. \& Pochocka-Szwarc, K., 2013. Heavy and light minerals as a tool for reconstructing depositional environments: an example from the Jałówka site (northern Podlasie region, NE Poland). Geologos 19, 47-66.

Zelčs, V. \& Markots, A., 2004. Deglaciation history of Latvia. [In:] J. Ehlers \& P.L. Gibbard (Eds): Quaternary Glaciations - Extent and Chronology, Part I: Europe, 225-243. Elsevier, Amsterdam.

Zelčs, V., Markots, A., Nartiös, M. \& Saks, T., 2011. Pleistocene glaciations in Latvia. [In:] J. Ehlers et al. (Eds): Developments in Quaternary Science. Quaternary Glaciations - Extent and Chronology. A Closer Look, 15, 221229. Elsevier, Amsterdam.

Zieliński, P., Sokołowski, R.J., Woronko, B., Jankowski, M., Fedorowicz, S., Zaleski, I., Molodkov, A. \& Weckwerth, P., in press. The depositional conditions of the fluvio-aeolian succession during the last climate minimum based on the examples from Poland and NW 
Ukraine. Quaternary International. doi.org/10.1016/j. quaint.2014.08.013.

Zieliński, T., 1993. Sandry Polski pótnocno-wschodniej osady $i$ warunki sedymentacji. [Sandurs of NE Poland - sediments and depositional conditions]. Silesian University Press, Katowice, 96 pp. [In Polish; English summary].

Zieliński, T., 2007. The Pleistocene climate-controlled fluvial sedimentary record in the Belchatow mine (central Poland). Sedimentary Geology 193, 203-209.
Zieliński, T., 2014. Sedymentologia. Osady rzek i jezior [Sedimentology. Deposits of rivers and lakes]. Adam Mickiewicz University Press, Poznań, 594 pp.

Zieliński, T. \& Pisarska-Jamroży, M., 2012. Jakie cechy litologiczne warto kodować, a jakie nie? [Which features of deposits should be included in a code and which not?]. Przeglad Geologiczny 60, 387-397.

Manuscript submitted 12 December 2014 Revision accepted 24 February 2015 